\title{
Environmental implications of soil erosion and sediment yield in Lake Hawassa watershed, south-central Ethiopia
}

Arega Degife ${ }^{1,2^{*}}$, Hailu Worku $^{3}$ and Shumete Gizaw ${ }^{4}$

\begin{abstract}
Background: Assessing soil erosion, sediment yield and sediment retention capacity of watersheds is one of the under-researched areas in watersheds of developing countries like Lake Hawassa watershed. The study examined soil erosion and sediment yield and their environmental implications in the Lake Hawassa watershed. The quantification and mapping were carried out using the Integrated Valuation of Ecosystem Services and Tradeoffs (InVEST) model. Data such as Land Use Land Cover (LULC), Digital Elevation Model (DEM), rainfall, soil, and management practice were used as input parameters.

Results: The empirical analysis confirmed that the watershed has a total soil loss of about $5.27 \mathrm{Mt}$ annually. The mean annual erosion rate from the watershed was estimated to be $37 \mathrm{t} \mathrm{ha}^{-1}$ year $^{-1}$. The estimated erosion rate was greater than the maximum tolerable erosion limit in Ethiopia $\left(2-18 \mathrm{t} \mathrm{ha}^{-1}\right.$ year $\left.{ }^{-1}\right)$. The total amount of sediment which was exported to the nearby streams and lakes in the watershed was estimated to be $1.6 \mathrm{t} \mathrm{ha}^{-1} \mathrm{year}^{-1}$. The water bodies receive a total of 226,690.3 t of sediment annually. Although higher soil loss and sediment export per unit of area were estimated from the highest slope gradients, greater contributions to the total soil loss and sediment export were computed from slopes with 5-30\% gradients. In terms of LULC, the highest contribution to the total soil loss was computed from cultivated land while the highest rate of soil loss per hectare was observed from bare land. Due to the existing vegetative cover, a total of $18.65 \mathrm{Mt}\left(130.7 \mathrm{t} \mathrm{ha}^{-1}\right.$ year $\left.^{-1}\right)$ of sediment was retained. Vegetation-covered LULCs such as forest, woodland, shrubland, and agroforestry revealed the highest sediment retention capacity. As a result of the increased soil erosion and sediment yield in the watershed, the drying-out of a small lake and the rise in the water level of Lake Hawassa were identified.
\end{abstract}

Conclusion: Most of the soil loss and sediment yield were contributed by a small part of the watershed. Thus, the results underscore the urgent need for targeted soil and water conservation measures of various types to ensure the sustainability of the watershed resources.

Keywords: Lake Hawassa, Sediment yield, Soil erosion, Sediment retention

*Correspondence: aregad2015@gmail.com

${ }^{1}$ Environmental Planning Program, Ethiopian Institute of Architecture, Building Construction, and City Development, Addis Ababa University (AAU), P.O.Box: 518, Addis Ababa, Ethiopia

Full list of author information is available at the end of the article

\section{Introduction}

Soil erosion is a global environmental problem that affects the provisioning and regulation of various ecosystem services (Bezabih et al. 2016; Borrelli et al. 2017; Hassen and Assen 2018; Aneseyee et al. 2020b). It is explained as the detachment, transportation, and deposition of soil materials by water, wind, ice, or gravity (Aksoy and Kavvas 2005; Panagos et al. 2015; Boakye et al. 2020). It is determined by factors such as Land Use 
Land Cover (LULC) changes, slope length and steepness, climate change, and soil properties (Gelagay and Minale, 2016; Lafforgue 2016). Soil erosion induced by running water is the leading cause of soil erosion and contributes the largest share of global soil degradation (Hurni 2002; Piccarreta et al. 2006; Rodrigo et al. 2015).

Soil erosion and the associated sediment yield are confirmed to have many environmental repercussions (Ionita et al. 2015). For instance, scholars affirm that soil loss has not only on-site impacts of increasing soil nutrient loss and reduced productivity of land (Pimentel, 2006; Haregeweyn et al. 2008, 2015, 2017; Fenta et al. 2020) but also off-site impacts of damaging infrastructure and deposition of sediment in downstream water resources (Tamene et al. 2011; Haregeweyn et al. 2017). Studies also attest that soil erosion and the resulting sedimentation have undesirable impacts on water holding capacity, water quality, and recreational value of downstream lakes and reservoirs (LIA 2011; Haregeweyn et al. 2012; deNoyelles and Kastens, 2016; Desta and Lemma 2017; Issaka and Ashraf 2017). In general, soil erosion and sediment yield have impacts of reducing ecosystem services and functions (Angassa 2014; Haregeweyn et al. 2012, 2015).

Many studies reported the effect of soil erosion on agricultural land and water resources. For instance, Tully et al. (2015) reported that more than 2/3rd of cropland degradation and the resulting productivity loss in Africa resulted from soil erosion. Besides, Degife et al. (2019) revealed that the loss of Lake Cheleleka and the degradation of the surrounding wetlands in the Central Rift Valley region of Ethiopia which was resulted from the erosion and deposition of sediment from the surrounding farmlands. Moreover, Moussa (2018) reported that Aswan High Dam of Egypt has lost 4\% of its water storage capacity over 48 years; Khashm el-Girba reservoir of Sudan has lost $53 \%$ of its water storage capacity in 46 years; Sennar reservoir of Sudan has lost $85 \%$ of its water storage capacity in 85 years, and Angereb reservoir in Ethiopia has lost $46 \%$ of its water storage capacity in 19 years due to problems of sedimentation.

A quantified estimation of soil erosion and sediment export and identification of the sources of sediments are of great interest in water resources management (Ambers 2001; Navas et al. 2009; Sharp et al. 2018). It helps to address the problem through proper planning and allows the design of better strategies for reducing the impacts on downstream irrigation, water treatment, recreation, and reservoir performance (Sharp et al. 2018).

Literature indicates that not all of the eroded soil in a watershed is transported out of it; a significant proportion of the eroded soil gets deposited at intermediate sites (Constable and Belshaw 1986; Swarnkar et al.
2018). A study by Constable and Belshaw (1986) revealed that only $10 \%$ of the total soil erosion is delivered to the watershed's outlet and reaches a natural water body. This exported soil offers the downstream influences of sediment deposition affecting the ecosystem and siltation of lakes and hydroelectric dams (Baral et al. 2014). Hence, it is important to quantify and differentiate between the level of soil erosion (i.e. the amount of soil eroded in a watershed), sediment export (i.e. the proportion of soil delivered to the stream and that reached a watershed's outlet), and sediment retention (i.e. the amount of sediment retained by vegetation and topographic features) in a watershed to identify the level of downstream impacts for effective water resources management (Sharp et al. 2018).

Although there were many studies on soil loss and sediment yield at the global level, most of them focused on the use of sophisticated instruments and well-experienced experts in data-rich environments (Jansson 1988; Syvitski and Milliman 2007). Such approaches are less practical in the context of developing countries including Ethiopia, where there are data scarcity and a lack of experienced experts (Haregeweyn et al. 2012). Studies in developing countries on soil erosion widely employ the Revised Universal Soil Loss Equation (RUSLE) to estimate soil loss (Hamel et al. 2015). However, the equation is not capable of estimating the sediment export and sediment retention capacity of a given watershed (De Vente et al. 2013). Since it doesn't determine sediment pathways from steep slopes to water bodies, it is difficult to examine possible downstream impacts, such as pollution and sedimentation (Jahun et al. 2015). The Integrated Valuation of Ecosystem Services and Tradeoffs (InVEST) sediment delivery ratio (SDR) model has the advantage of addressing the limitations of the RUSLE thus enabling the combined estimations of soil loss, sediment export, and sediment retention through characterizing the hydrological connectivity of a given watershed (Sharp et al. 2018). Hence, this study employs the InVEST model and seeks to utilize the advantages of the model's comprehensive estimation of soil loss, sediment export, and sediment retention of a watershed.

In Ethiopia, studies show that soil erosion and the resulting sediment yield are common problems (Hurni 1993; Bantider 2007; Erkossa et al. 2015; Gelagay 2016; Desta and Lemma 2017; Haregeweyn et al. 2017). However, the levels of erosion and sediment yield reported show spatial variation depending on the type of soil, climate, topography, population density, farming, management practices, and methods used. Such variations signify that site-specific studies and locally adaptable erosion and sediment mitigation strategies are still necessary to minimize the impacts of accelerated erosion and 
sedimentation. Additionally, although the studies indicate soil erosion and related sediment yield in the country have led to various environmental problems, there were very limited studies on the estimations of erosion and sediment yield in the Rift Valley Lakes Basin of Ethiopia. Moreover, studies that integrate the estimations of soil loss, sediment export, and sediment retention along with studying their spatial variations with land use and slope are still scanty, if not unavailable for the Rift Valley Lakes Basin of Ethiopia in particular (Sadeghi et al. 2008; Aneseyee et al. 2020a, b).

Therefore, the present study was conducted in an environmentally fragile watershed of Lake Hawassa in the south-central Rift Valley region of Ethiopia. Although there were some prior studies that examined the degradation of Lake Hawassa (Geremew 2000; Gebre-Mariam and Desta 2002; Gebreegziabher 2004; Esayas 2010), the integrated assessment of soil erosion, sediment yield, and sediment retention at watershed scale were not considered in the studies. It is scientifically proved that identifying the magnitude and spatial variation of the sources of pressures on natural resources is the major requirement for making proper conservation planning and management (FEI 2003). Hence, the purpose of this study was to quantify and map the spatial variations of soil erosion, sediment export, and sediment retention along with their environmental implications in the Lake Hawassa Watershed of Ethiopia. This will help to understand the level of stress on natural resources and make informed decisions before irreversible damages happen to the Lake and the associated watershed resources.

\section{Materials and methods}

\section{Study site description}

Lake Hawassa watershed is located in a closed drainage system. It has an area of 142,661 ha. Its formation is associated with the tectonic activity which formed the Great East African Rift System and the Lakes Region in Ethiopia (Chorowicz 2005; Macgregor 2015). Geographically, the watershed is situated between $6^{\circ} 45^{\prime} \mathrm{N}$ and $7^{\circ} 15^{\prime} \mathrm{N}$ Latitude and $38^{\circ} 15^{\prime} \mathrm{E}$ and $38^{\circ} 45^{\prime} \mathrm{E}$ Longitude (Fig. 1). The dominant landscapes characterizing the watershed are the volcanic mountains forming the surrounding escarpments and flat plains lying at the foothills of the mountains. In terms of elevation, the watershed ranges from 1680 to $2550 \mathrm{~m}$ above sea level.

Before early settlement and agricultural land expansion, the watershed was predominantly covered by Podocarpus falcatus and Juniperus procera in the Moist Woina Dega (moist mid-highland) and by acacia and shrubs in the Dry Woina Dega (dry mid- highland) (Dessie 2007). The watershed consists of important ecosystems such as

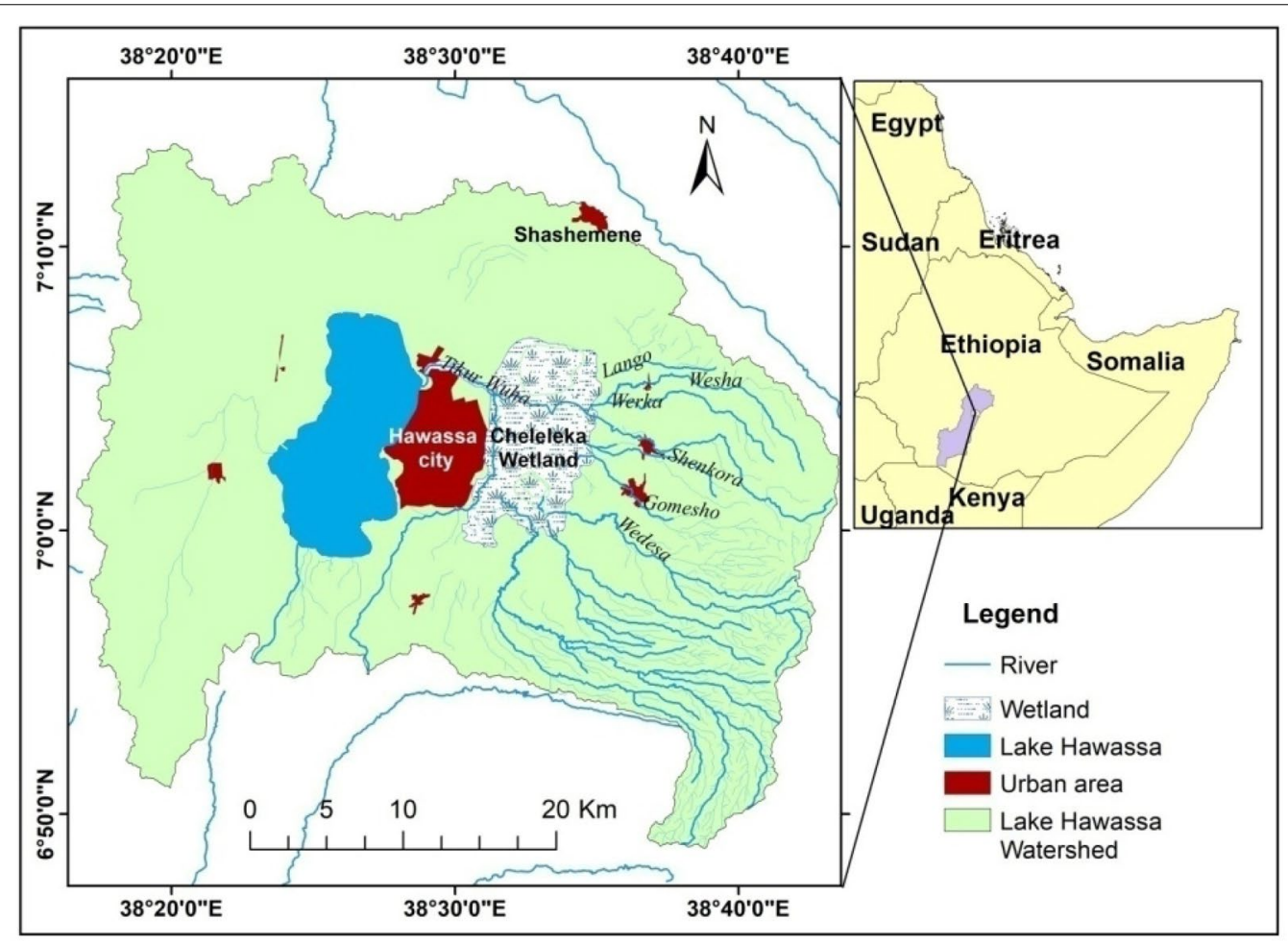

Fig. 1 Location map of the study area 
lakes, wetlands and small streams (Fig. 1). The streams flow from the eastern escarpment and are later collected into one major river of Tikur Woha that finally joins Lake Hawassa.

The watershed is characterized by high population growth. According to the estimate by the Federal Government of Ethiopia (Ministry of Water, Irrigation, and Energy (MoWIE)), in 2007, the total Population of the watershed was estimated to be 839,585 , of which $23 \%$ was urban. In 2020, the projected population, by Rift valley Lakes Basin Master Plan Studies, was 2,491,295.

The dominant economic activity in the watershed was agriculture, which was characterized by subsistence level mixed cropping with some commercial farming and livestock production.

\section{Data analysis tool}

Various supporting models are available for quantifying and mapping erosion and sediment yield in a watershed (Morgan 2009; Biggs et al. 2015; Farhan and Nawaiseh 2015; Karabulut et al. 2016; Redhead et al. 2016; Schmalz et al. 2016). One group of empirical soil loss models is the Universal Soil Loss Equation (USLE), including the Revised Universal Soil Loss Equation (RUSLE), the Revised Universal Soil Loss Equation version 2 (RUSLE2), and the Modified Universal Soil Loss Equation (MUSLE). The RUSLE is a simple model with few data requirements compared to other models which are complex that require intensive data and resources (Sharp et al. 2018). The simplicity of the RUSLE has been incorporated into more sophisticated soil erosion models to help with natural resources management and decision-making, including the Agricultural Non-Point Source model (AGNPS), the Chemical Runoff and Erosion from Agricultural Management Systems model (CREAMS), the Sediment River Network model (SedNet) and the Integrated Valuation of Ecosystem Services and Tradeoffs model (InVEST) (Merritt et al. 2004; Aksoy and Kavvas 2005; de Vente and Poesen 2005; Sharp et al. 2018). In this study, considering the serious data scarcity in the study area, the InVEST model was selected to quantify and map, erosion and sediment yield.

The InVEST sediment delivery model estimates the relative contributions of sediment from each parcel of a landscape in a spatially explicit manner, offering insight into how changes in LULC patterns affect the annual sediment yield. It helps the integrated study of soil loss, sediment export, and sediment retention in a given watershed as it is capable of determining the sediment pathways from hill slopes to water bodies. This is important to examine possible downstream impacts of sedimentation (Jahun et al. 2015). However, the model has some limitations as it is based on annual averages, which disregard extremes and sub-annual patterns of sediment delivery (Sharp et al. 2018). Despite the limitations, the model still provides a useful assessment of how landscape scenarios may affect the annual delivery of sediment. Besides, compared to other sophisticated and data-intensive models, InVEST model was preferred for this study due to its requirement of fewer input parameters, availability of the required input spatial data, and compatibility with various GIS data. Most importantly, the model uses the RUSLE and some of the input parameters of the RUSLE equation were calibrated for the Ethiopian context (Hurni 1985) which can readily be used in the model. Above all, very limited studies in Ethiopia and probably no other studies in the Lake Hawassa watershed were conducted employing this model.

\section{Data used}

Various factors including LULC, soil, topography, climate, and management practices affect the rate of soil erosion, sediment yield, and sediment retention in a watershed. In this study, multiple data including spatial and non-spatial and field observation to triangulate data were utilized. The data used in the study include watershed boundary, LULC data, rainfall erosivity (R-factor), soil erodibility factor (K-factor), DEM, and biophysical table.

\section{Watershed boundary}

A shapefile of the Lake Hawassa watershed was one of the input data to InVEST model. It was extracted from DEM using ArcGIS and used to determine the boundaries of the watershed.

\section{LULC data}

The InVEST sediment delivery ratio model requires a raster LULC dataset with an integer LULC code for each cell. The LULC dataset was extracted from the Landsat image of 2017 which was downloaded from the USGS website (https://earth.explorer.usgs.gov) (Fig. 2). Before classifying the image; sub-setting, layer stacking, and image enhancement were made as image pre-processing. The LULC dataset was then created by employing supervised classification using the maximum likelihood algorithm in ERDAS IMAGIN 2014 environment (Fig. 2). The accuracy of the LULC classification was $93 \%$ with over all kappa of 0.90 .

\section{Rainfall erosivity ( $R$-factor)}

The Rainfall erosivity (R) factor is the power of rain to initiate soil erosion. It is the energy of a given storm that depends on the amount, duration, intensity, energy and size of raindrops, pattern of rainfall, and level of the resulting runoff (Renard et al. 1997; Farhan and 


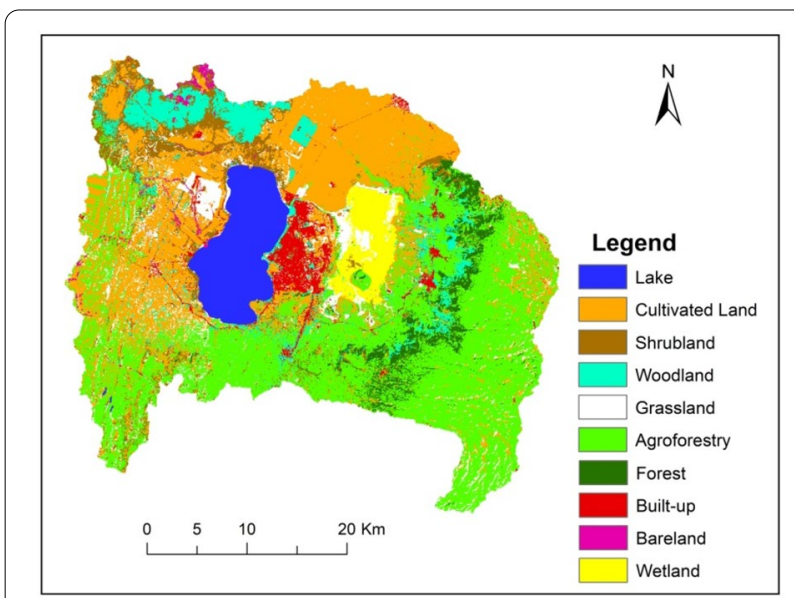

Fig. 2 LULC map of Lake Hawassa Watershed

Nawaiseh 2015). It is considered the most prominent factor that affects soil erosion and sediment yield (Wischmeier and Smith 1978). It is determined by the mean annual $\mathrm{EI}_{30}$, which is the product of long-term records of the kinetic energy of storm (E) and the maximum 30 min intensity $\left(\mathrm{I}_{30}\right)$ (Renard et al. 1997; Morgan 2009; Kouli et al. 2009). However, such data are not readily available at weather stations of most third-world countries, including Ethiopia, owing to the lack of automatic rain gauges (Hurni 1985). Hence, R-factor is alternatively estimated from the long-term mean annual rainfall values of a watershed (Renard et al. 1997). In this study, R-factor was computed based on the regression equation developed by Hurni (1985) for the highlands of Ethiopia (Eq. 1).

$$
\mathrm{R}=-8.12+(0.562 * \mathrm{P})
$$

where, $\mathrm{R}$ is the rainfall erosivity factor and $\mathrm{P}$ is the mean annual Precipitation $(\mathrm{mm})$.

In the process of calculating $R$ values, first, the daily average precipitation data were summed to obtain the mean annual rainfall amount (in $\mathrm{mm}$ ) at each station. However, since the annual rainfall erosivity value significantly fluctuates at spatial and temporal scales, a minimum of 15 years of data is required to achieve proper estimates of rainfall erosivity of a watershed (Panagos et al. 2015; Yesuph and Dagnew 2019). The variation in altitude may also cause the variation in the distribution of rainfall. Hence, to adequately consider the variation of rainfall in the entire watershed, more than 30 years of rainfall data from 6 weather stations (from within and around the watershed with varied altitudinal locations) were used following a method employed by Wolka et al. (2015), Esa et al (2018), and Yesuph and Dagnew (2019).
Therefore, the mean annual rainfall data at each station was used to generate gridded rainfall data using the Inverse Distance Weighted (IDW) interpolation technique in ArcGIS 10.3. The IDW geostatistical interpolation method was preferred because it makes it easier to generate relatively accurate rainfall gridded data from known sample points located at closer distances than those located far from the points of unknown values. The method was also selected for the reason that it enables better interpolation of the required data from grid-based irregularly spaced samples (Li and Heap 2008).

Finally, the raster rainfall data which was generated using the IDW method was used to compute rainfall erosivity (R) raster data using Eq. 1 in a raster calculator of ArcGIS. A similar approach was used to compute R-factor in Ethiopia by Bewket and Teferi (2009), Shiferaw (2011), Wolka et al. (2015), Esa et al. (2018), and Yesuph and Dagnew (2019). The computed R-value ranged from 457.6 to 646.4 MJ mm ha ${ }^{-1} \mathrm{~h}^{-1}$ year $^{-1}$ (Fig. 3).

For evaluating the uncertainty in the estimation of the R-factor, Hurni (1985) tested the equation against observed data from test plots of six research units of the Soil Conservation Research Project (SCRP) in Ethiopia. It was proved that the R-factor value strongly correlates with the Ethiopian highland types of rainfall, with $r=0.93$ (Hurni 1985). Many studies in Ethiopia also reported successful estimation of soil loss by using the equation (Bewket and Teferi 2009; Shiferaw 2011; Meshesha et al. 2012; Amsalu and Mengaw 2014; Wolka et al. 2015; Gelagay and Minale 2016; Esa et al. 2018; Gashaw et al. 2018; Asmamaw, and Mohammed 2019; Yesuph and Dagnew 2019; Girmay et al. 2020).

\section{Soil erodibility ( $K$-factor)}

One of the requirements for InVEST model is soil erodibility data. Soil erodibility $(\mathrm{K})$ is the biophysical and chemical properties of the soil indicating the susceptibility of soil to erosion (Renard et al. 1997; Farhan and Nawaiseh 2015; Panagos et al. 2015). The K-factor reveals the ease with which the soil is removed by splash and surface flow. It also indicates the effect of soil properties on soil loss and the susceptibility of soil to erosion.

Literature reveals that various approaches have been used by scholars to determine erodibility of soil depending on data availability (Hurni 1985; Römkens et al. 1997). For instance, a study by Hurni (1985) indicated that the $\mathrm{K}$-factor can be determined depending on soil texture, organic matter content, permeability, grain size distribution, and other factors. In the present study, due to the paucity of data, the K-values for each soil type were determined by using the values adopted from Hurni (1985) by the Ethiopian Rift valley Lakes Basin Master Plan Studies. The soil units' spatial data 

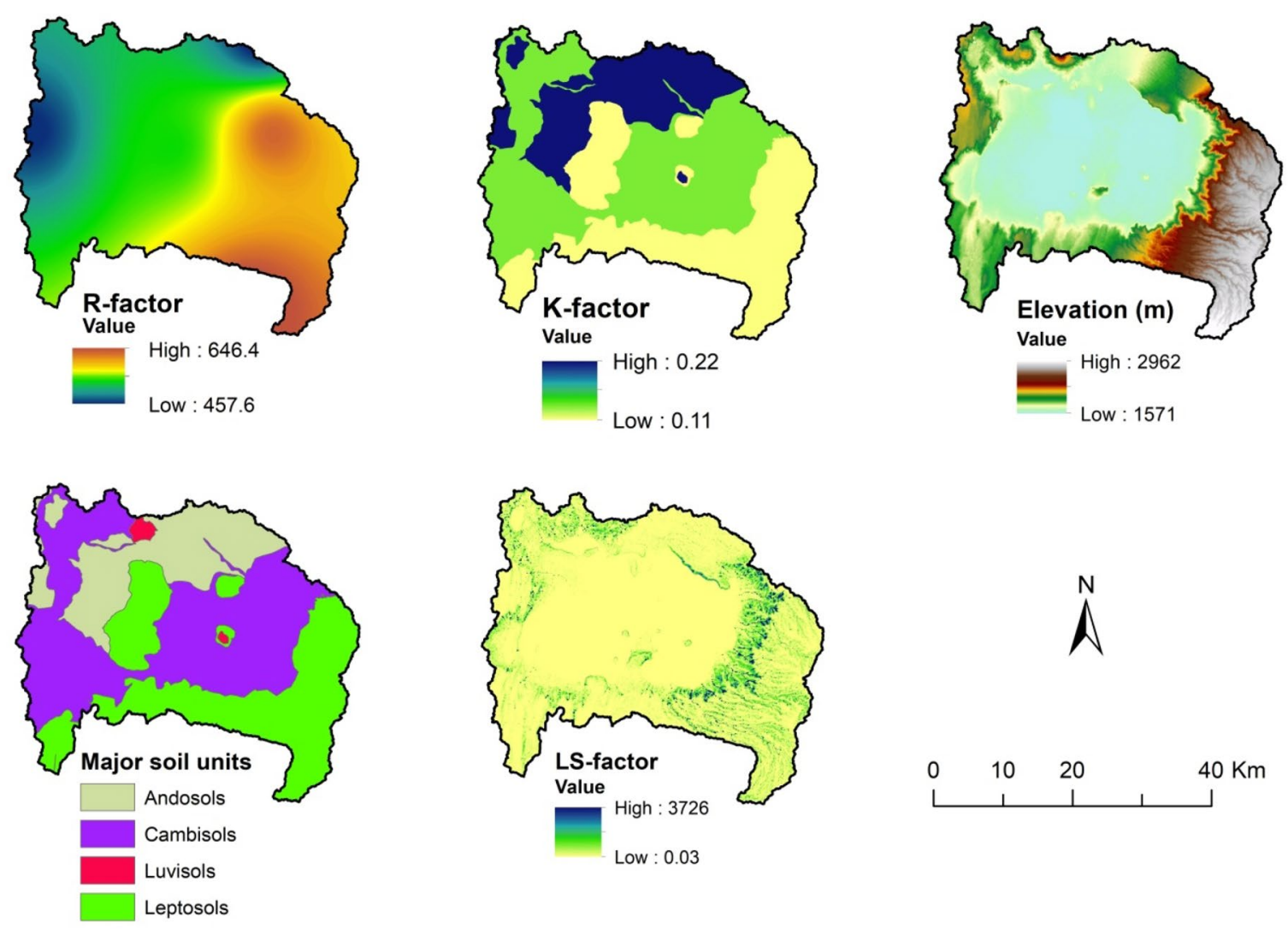

Fig. 3 Spatial distributions of R-factor, K-factor, elevation, major soil units, and LS-factor

of the watershed was extracted from the Rift Valley Lake Basin Master Plan study. The soil data contains four dominant soil units namely; Andosols, Cambisols, Luvisols, and Leptosols (Fig. 3).

Finally, the soil erodibility (K) layer of the watershed with a grid size of $30 \mathrm{~m}$ was produced using ArcGIS 10.3 "Spatial Analyst" tool. The $\mathrm{K}$ value ranges from 0 to 1 , where 0 indicates less and 1 reveals high susceptibility to erosion risk (Farhan and Nawaiseh 2015). The $\mathrm{K}$-factor values for the soil types of the Lake Hawassa watershed were presented in Table 1 and Fig. 3.

Table 1 Soil erodibility factor

\begin{tabular}{ll}
\hline Soil type & K-factor \\
\hline Andosols & 0.2 \\
Cambisols & 0.13 \\
Luvisols & 0.11 \\
Leptosols & 0.22 \\
\hline
\end{tabular}

To reduce uncertainty in the estimation of k-values and validate the estimated values, Benavidez et al. (2018) recommended checking the derived $\mathrm{K}$-values for specific areas against previously published $\mathrm{K}$ - factor values for comparable sites and soil types. Hence, the results were checked against the results of previous studies in Ethiopia (e.g. Hurni 1985; Wolka et al. 2015; and Yesuph and Dagnew 2019). Besides, field-based soil sample color identification was carried out using a Munsell color chart as per the recommendation of Hurni (1985) and Yesuph and Dagnew (2019) for comparing the identified soil types with K-values derived for the Ethiopian highlands based on soil color.

\section{Digital elevation model (DEM)}

One of the requirements for the RUSLE equation was the LS-factor. In the calculation of slope length $(\mathrm{L})$ and slope gradient (S) in sediment delivery calculations, a DEM with $30 \mathrm{~m}$ spatial resolution which was corrected by fillingin sinks was used as a major input to InVEST model. The LS-factor is a combined factor that indicates the effects of slope length and slope gradient and determines the velocity 
and volume of runoff and the transport of soil particles (Prasannakumar et al. 2012). The steepness and length of slope determine the rate of soil erosion (Gashaw et al. 2018), through a greater accumulation of runoff (Wischmeier and Smith 1978).

In RUSLE, the LS-factor represents a ratio of soil loss per unit area on a site to the corresponding loss from a "standard" 9\% slope steepness on a $22.13 \mathrm{~m}$ long plot (Renard et al. 1997; Kaltenrieder 2007). LS-factor increases with slope length and slope gradient. The higher the value of the LS-factor of land the higher will be the velocity and erosive power of runoff (Wischmeier and Smith 1978; Renard et al. 1997).

In the original USLE method of calculating LS-factor, only slope angle and length over uniform slopes at a unit plot or field scale are required. However, this method has limited applicability to large field scale and complex topographies. The method assumes that slopes have uniform gradients. In the case of irregular slopes and complex gradients, the method requires the slopes to be divided into smaller segments of uniform gradients for accurate results (Wischmeier and Smith 1978). The manual measurement of slopes and dividing them into smaller segments at the plot or small field scale may be manageable; however, it is difficult when applying it at larger scales and complex topographies.

Hence, to overcome the limitations of the original method of calculating LS factor developed by Wischmeier and Smith (1978), a method developed by Desmet and Govers (1996) that includes contributing area and flow accumulation for calculating the LS-factor in topographically complex areas and larger field scales was found to be helpful. With advances in GIS technology and the use of DEM, the method of calculating the upslope contributing area and the resulting LS-factor has got wider acceptance and allows for considering more topographically complex landscapes at the scales of watersheds and regions (Moore and Burch 1986; Desmet and Govers 1996; Panagos et al. 2015; Benavidez et al. 2018). This method of using flow accumulation for slope length and steepness for the calculation of LS-value considers the convergence and divergence of flow, which is vital when considering soil erosion over a complex topography (Wilson et al. 2000).

As indicated by Sharp et al. (2018), since it is difficult to make direct field measurements to determine LS-factor in complex topography, the InVEST model calculates the LSfactor from the input DEM using an equation developed by Desmet and Govers (1996):

$$
L S i=S i \frac{\left(A_{i-i n}+D^{2}\right)^{m+1}-A_{i-i n}^{m+1}}{D^{m+2} * x_{i}^{m} * 22.13^{m}}
$$

where, $S_{i}$ represents the slope of a grid cell computed as function of slope radians $\theta$, with $S=10.8 \cdot \sin (\theta)+0.03$ for $\theta<9 \%$ while $S=16.8 \cdot \sin (\theta)-0.50$ for $\theta \geq 9 \%$; $A_{i-i n}$ represents the contributing area in $m^{2}$ at the inlet of a grid cell which is computed based on the d-infinity flow direction method; $D$ indicates the grid cell linear dimension in $m ; x i=|\sin \alpha i|+|\cos \alpha i|$ where $\alpha i$ stands for the aspect direction for grid cell $i ; m$ is the RUSLE slope length exponent of LS factor which is based on Oliveira et al. (2013), where: $m=0.2$ for slope $\leq 1 \%, m=0.3$ for $1 \%<$ slope $\leq 3.5 \%, m=0.4$ for $3.5 \%<$ slope $\leq 5 \%, m=0.5$ for $5 \%<$ slope $\leq 9 \%$, and $m=\beta /(1+\beta)$ where $\beta=\sin$ $\theta / 0.0986 /\left(3 \sin \theta^{0.8}+0.56\right)$ for slope $\leq 9 \%$.

In line with this, many studies suggest using DEM in the calculation of the LS-factor (Moore and Wilson 1992; Mitasova and Mitas 1999; Simms et al. 2003; Yesuph and Dagnew 2019). Hence, in this study, a $30 \mathrm{~m}$ spatial resolution SRTM DEM was used as input for the calculation of the LS-factor. Finally, the calculated LS-values ranged from 0.03 in low flow concentration level slope land to 3,725.98 in very steep slope areas (Fig. 3).

\section{Biophysical table}

For the calculation of erosion and sediment yield, a ".csv" table containing data on cover-management and support practice factors corresponding to each of the LULC classes was required. In the table, rows were LULC classes and columns were named as "lucode", "rusle_c" and "rusle_p", in which they represent land use code, land cover and management factor, and support practice factor, respectively.

The "lucode" was land use code of a unique integer for each LULC class (e.g., 1 for cultivated land, 2 for agroforestry, etc.) which was matched to the LULC raster input.

The "rusle_c" values indicate how the covers of the land types (such as cultivated land, agroforestry, etc.) affect soil loss (Renard et al. 1997; Haregeweyn et al. 2017). Determining "rusle_c" values entails data related to soil management conditions, the nature of plant canopy and crop residues as a soil cover, soil surface roughness, and the level of soil moisture. However, estimating each of these parameters was difficult due to the paucity of data (Renard et al. 1997; Farhan and Nawaiseh 2015). In most cases, LULC map and Normalized Difference Vegetation Index (NDVI) are used for "rusle_c" value estimation (Karaburun 2010; Lin et al. 2017). In this study, the LULC map approach was selected since it gives a comparatively precise "rusle_c" value than the NDVI (Lin et al. 2017). To assign "rusle_c" values for each LULC class, the raster data was converted to vector format using ArcGIS10.3. The "rusle_c" values were assigned based on literature suggestions for the highlands of Ethiopia (see Table 2). Benavidez et al. (2018) recommends that a simpler 
Table 2 Adopted values of "rusle_c" factor for different LULC classes

\begin{tabular}{lll}
\hline LULC type & “Rusle_c"values & References \\
\hline Lake & 0 & Girma and Gebre (2020) \\
Cultivated land & 0.15 & Hurni (1985), Bewket and Teferi (2009) \\
Shrubland & 0.05 & Tamene et al. (2014), Haregeweyn et al. (2013) \\
Woodland & 0.06 & Eweg and van Lammeren (1996) \\
Forest & 0.01 & Hurni (1985); Zerihun et al. (2018) \\
Grassland & 0.05 & Hurni (1985), Bewket and Teferi (2009); \\
Agroforestry & 0.06 & Eweg and van Lammeren (1996) \\
Wetland & 0.001 & Wischmier and Smith (1978); Hurni (1985) \\
& & and Kaltenrieder (2007) \\
Bareland & 1 & Eweg et al. (1998); Hurni (1985) \\
Built-up & 0.05 & Moges and Bhat (2017)
\end{tabular}

method of determining the "rusle_c" values is using values from studies that have reported values for similar LULC, or from studies conducted in the same local area or region. However, the definition of LULC type differs between studies. Identifying the variation between LULC classifications before applying "rusle_c" values from the studies was important. Hence, to reduce uncertainty in the estimated values of "rusle_c", values from those studies that have similar LULC classifications were adopted. Finally, the adopted values were found to be floatingpoint values between 0 and 1 .

The "rusle_p" factor reveals the role of land conservation practices in minimizing the level of soil erosion (Renard et al. 1997). It is determined by the type of conservation measures implemented in the field. However, the "rusle_p" factor is the least reliable factor due to the difficulty in measuring the characteristics of conservation practices in the field (Renard et al. 1991). In fact, some soil and water soil conservation measures have been practiced in the watershed. However, the observed conservation practices in the field were either scanty, poorly designed and implemented, or totally damaged due to poor follow-up or maintenance. As a result, it is difficult to use these support practices as input data to determine soil erosion in the watershed.
Due to the difficulty in accurately determining support practice factors, many studies ignore them from analysis (Adornado et al. 2009; Renard et al. 1997; Schmitt, 2009). However; as suggested by Wischmeier and Smith (1978), Hurni (1985), Sharma et al. (2011), and Yesuph and Dagnew (2019); this study used "rusle_p" values of various LULC classes. Like the "rusle_c" factor, values for the "rusle_p" factor were taken from the literature.

To this end, the watershed was classified into cultivated land and other LULC types as recommended by Wischmeier and Smith (1978). Also, as suggested by scholars who carried out similar studies in the Ethiopian context (Gelagay and Minale, 2016; Esa et al. 2018; Gashaw et al. 2018; Yesuph and Dagnew, 2019), cultivated lands were further categorized into six slope classes (Table 5) for the reason that land management activities are highly dependent on slope classes. Then, the cultivated lands under each slope class were given $\mathrm{p}$-values while the remaining LULC classes were assigned with a uniform default value of 1 based on the literature recommendation. The resulting values vary between 0 and 1 with the lower values indicating comparatively better soil erosion control measures (Table 3).

Table 3 Adopted values of "rusle_p" factor

\begin{tabular}{llll}
\hline LULC & Slope category & $\begin{array}{l}\text { “Rusle_p” } \\
\text { factor }\end{array}$ & References \\
\hline Cultivated land & $0-5$ & 0.10 & Wischmeier and Smith (1978), Bewket and Teferi (2009), Gelagay and Minale (2016), Esa et al. \\
& $5-10$ & 0.12 & $(2018)$, Gashaw et al. (2018); Yesuph and Dagnew (2019) \\
& $10-20$ & 0.14 \\
& $20-30$ & 0.19 \\
& $30-50$ & 0.25 \\
& $50-100$ & 0.33 & \\
Non-cultivated LULCS & All & 1 \\
\hline
\end{tabular}




\section{Model structure}

InVEST sediment yield model helps the mapping and quantification of annual soil erosion, sediment export, and sediment retention in a watershed. It calculates soil erosion and sediment delivery in a spatially-explicit manner working at the spatial resolution of the input DEM raster. For each cell of the output data, the model primarily calculates the amount of eroded soil and then computes the sediment delivery ratio (SDR), which is the amount of soil loss that reaches a watershed's outlet (Sharp et al. 2018). The approach was developed by Borselli et al. (2008) and has received increasing attention in recent years (Cavalli et al. 2013; López-vicente et al. 2013).

\section{Annual soil erosion}

To determine the amount of annual soil loss on pixel $i$, rusle $_{i}\left(t y r^{-1}\right)$, the model uses the RUSLE (Sharp et al. 2018). The equation estimates water-caused soil loss for varying climatic, soil, and topographic conditions. Since its development, RUSLE has been continuously improved to more precisely calculate soil loss and to adapt to a varying range of geographic areas. The equation is widely applied and is explained by the following equation (Eq. 3) (Renard et al. 1997):

$$
\text { rusle }_{i}=R_{i} * K_{i} * L S_{i} * C_{i} * P_{i}
$$

where, rusle $e_{i}$ is the average annual soil loss in $\mathrm{t}$ $\mathrm{ha}^{-1}$ year $^{-1}$; $R i$ is the rainfall erosivity in mega joules millimeter per hectare per hour per year [MJ $\mathrm{mm}$, $\left(\mathrm{ha}^{-1} \mathrm{~h}^{-1}\right.$ year $\left.\left.^{-1}\right)\right]$ which is derived from daily precipitation data; $K_{i}$ is the soil erodibility factor in ton hectare hour hectare ${ }^{-1}$ megajoule ${ }^{-1} \mathrm{~mm}^{-1}\left(\mathrm{t} \mathrm{ha}^{-1} \mathrm{~h} \mathrm{MJ}^{-1} \mathrm{ha}^{-}\right.$ ${ }^{1} \mathrm{~mm}^{-1}$ ) which is derived from data on soil types; $L S_{i}$ is the slope length-gradient factor which is the length of the slope and percent of the slope steepness derived from DEM (dimensionless); $C_{i}$ is the land cover and management factor (dimensionless) which is derived from LULC classification of satellite image data; and $P_{i}$ is the support practice factor which accounts for soil erosion control measures (dimensionless) derived from literature.

\section{Annual sediment export}

The sediment export is the proportion of soil loss reaching the nearby streams (Sharp et al. 2018). The model estimates the exported sediment based on the work by Borselli et al. (2008). Since the estimation of SDR at each pixel is determined by the upslope area and downslope flow path, the model first computes the connectivity index $(I C)$ which is given by the following equation:

$$
I C=\log _{10}\left(\frac{D_{u p}}{D_{d n}}\right)
$$

$D_{u p}$ is the upslope component and given by:

$$
D_{u p}=\overline{C S} \sqrt{A}
$$

where, $\bar{C}$ is the mean $C$ factor of the upslope contributing area; $\bar{S}$ is the mean slope gradient of the upslope contributing area; and $A$ is the upslope contributing area in $\mathrm{m}^{2}$, which the model delineates based on the D-infinity flow algorithm (Tarboton 1997; Sharp et al. 2018).

The downslope component $\left(D_{d n}\right)$ is defined as:

$$
D_{d n}=\sum_{i} \frac{d_{i}}{C_{i} S_{i}}
$$

where $d_{i}$ is the length (in $\mathrm{m}$ ) of the flow path along the ith cell based on the steepest downslope direction; $C_{i}$ and $S_{i}$ represent the $C$ factor and the slope gradient of the ith cell, respectively. The model determines the downslope flow path using the D-infinity flow algorithm (Tarboton, 1997; Sharp et al. 2018).

Then, the model computes the SDR ratio for a pixel i from the connectivity index (IC) based on Vigiak et al. (2012):

$$
S D R_{i}=\frac{S D R_{\max }}{1+\exp \left(\frac{I C_{0}-I C_{i}}{k}\right)}
$$

where $S D R_{\text {max }}$ is the maximum hypothetical SDR, set to an average value of 0.8 (Vigiak et al. 2012), and $I C_{0}$ and $k$ are calibration values that determine the shape of the SDR-IC relationship (increasing function) (Sharp et al. 2018)

The sediment load from a given pixel i, $E i\left(t \mathrm{~h} a^{-1} y r^{-1}\right)$ is given by:

$$
E_{i}=u_{s l e_{i}} * S D R_{i}
$$

The total sediment load from the watershed, $E$ $\left(t \mathrm{~h} a^{-1} y r^{-1}\right)$ is given by:

$$
E=\sum_{i} E_{i}
$$

\section{Annual sediment retention}

For estimating the sediment retention service that the watershed provides, the model uses as a benchmark a hypothetical scenario where the whole watershed is cleared to bare soil. The value of the sediment retention service is then estimated based on the difference between the sediment export from this bare soil 
watershed and that of the watershed under the existing land management and vegetative cover (Sharp et al. 2018).

\section{Data analysis techniques}

To combine the datasets and run the model, all the input data were set to the same spatial resolution, projection, and reference system. The Landsat image and the DEM used in this study were with $30 \mathrm{~m}$ cell sizes and all the remaining data were processed to the same cell size and reference system. After preparing and arranging the input data using ERDAS IMAGIN 2014 and ArcGIS 10.3, all the parameters were combined using InVEST 3.8.9 model to generate final estimated values of soil erosion, sediment yield, and soil retention.

The outputs from the InVEST sediment yield model included the amount of sediment eroded in the catchment, the sediment retained by the vegetation and topographic features as well as the sediment load beyond the retention capacity of the vegetation and topographic features which are delivered to a water body at an annual time scale. These outputs are important to estimate the regulatory capacity of the watershed's LULC for soil erosion and sediment protection services, which are vital in studying the management of the lake, reservoir, and water quality in streams (Sharp et al. 2018).

Finally, the spatial distribution of the estimated mean annual soil erosion, sediment export, and soil retention were presented using maps and tables. The computed results were categorized into different intensity classes and ranges of soil loss, sediment export, and soil retention rates following literature recommendations such as FAO guideline (FAO 2006) and personal expertise, with some adjustment to fit local circumstances as depicted in Table 4. Besides, the spatial variations in rates of soil erosion, sediment export, and soil retention in different LULC categories and slope classes were computed by using the zonal statistics tool of ArcGIS 10.3.

\section{Model uncertainties}

The InVEST model uses the RUSLE to estimate soil loss (Sharp et al. 2018). The equation was originally developed in the United States of America (USA) based on the studies conducted on agricultural lands at the farm plot scale (Wischmeier and Smith 1978). Due to its relatively low data requirements compared to more sophisticated soil loss models, it has been used by many studies in different countries, at varied scales, and in various agroclimates; making it preferable to apply in areas with data scarcity. Although, there are uncertainties in estimating soil erosion using the RUSLE, very few studies critically discussed it in soil erosion modeling using RUSLE (Benavidez et al. 2018). The uncertainties usually emerge from the simple empirical nature of the model, the poor availability of long-term reliable input data for modeling, and the lack of validation data with which to verify model outputs, particularly in data-scarce regions. In fact, uncertainty is not an exception to the RUSLE application (Wischmeier and Smith 1978; Naipal et al. 2015; Benavidez et al. 2018). Generally, greater uncertainties happen when applying more sophisticated models which use detailed and larger numbers of input data (Hernandez et al. 2012).

The most commonly cited uncertainty in RUSLE stems from applying the equation in regions other than the USA (Kinnell 2010; Sadeghi et al. 2014). Besides, since the model was built based on small-scale studies of agricultural plots, it shows greater uncertainties when upscaling the original RUSLE on farm plot scale to the catchment or regional scale (Nagle et al. 1999; Naipal et al. 2015). Hence, applying the RUSLE for a specific area requires careful use of each input parameter and being mindful of the greater uncertainty in model predictions (Wischmeier and Smith 1978; Benavidez et al. 2018). Benavidez et al. (2018) suggest that determining RUSLE sub-factors that suit particular study sites is one method of addressing the model's uncertainty and regional applicability. Given that SDR is affected by characteristics similar to those of RUSLE, minimizing the uncertainty in RUSLE sub-factors helps to minimize the uncertainty in sediment yield estimations. The improvement and modifications to the RUSLE input parameters have made it usable at various climatic regions and larger spatial scales, including the global scale (Naipal et al. 2015). Bringing together published estimates of RUSLE input parameters from different climatic regions was found to be important for deciding the most appropriate equation to use in a particular study site, and verify the derived input parameter values (Benavidez et al. 2018).

In this study, various approaches were used to minimize the uncertainties in the estimation of soil loss as well as sediment yield. To reduce uncertainty in the R-factor, for instance, the literature indicates that detailed data is required for the standard calculation of rainfall erositivity (Wischmeier and Smith 1978). However, studies in areas with less detailed data usually use alternative equations depending on the temporal resolution and availability of the rainfall data. Some studies also suggest the importance of using and testing against observed data or R-values derived by previous applications in the same study area or in study areas with similar climatic regimes to reduce uncertainty in the R-factor (Benavidez et al. 2018). In this study, as indicated in "Rainfall erosivity (R-factor)" section, an equation developed by Hurni (1985) which was tested 
against observed data in the context of Ethiopian highlands was used. The equation was applied by many studies in the country and found to generate comparable results. In addition, the uncertainty in K-values was reduced by using the K-values of previously published studies which were conducted in comparable study sites and soil types in Ethiopia as per the recommendation of Hurni (1985); Wolka et al. (2015); Benavidez et al. (2018), and Yesuph and Dagnew (2019). The uncertainty in LS-factor was also reduced by using a method developed by Desmet and Govers (1996) that considers contributing area and flow accumulation in computing the LS-factor in topographically complex areas. The method has achieved a wider acceptance for it allows for considering more topographically complex landscapes at the larger geographic scales (Moore and Burch 1986; Desmet and Govers 1996; Panagos et al. 2015; Benavidez et al. 2018). Moreover, in managing the uncertainty in C-factor, Benavidez et al. (2018) and Yesuph and Dagnew (2019) suggest a method of determining the C-factor by referencing studies that have reported values for similar LULC or by adopting values from studies done in the same area or region. Hence, this study adopted C-factor values from those studies that have similar LULC classifications in the Ethiopian context. Furthermore, like the $\mathrm{C}$ factor values, the $\mathrm{P}$ factor values were taken from literature as per the recommendations of Wischmeier and Smith (1978); Adornado et al. (2009); Renard et al. (1997); Schmitt (2009), Sharma et al. (2011); Benavidez et al. (2018) and Yesuph and Dagnew (2019).

Despite the uncertainties, the RUSLE is still widely utilized because of the simple nature of the model and low data requirements compared to more complex physically-based models. The simplicity of the model allows its application in areas where there are scarce data for more complex models that entail large input data (de Vente and Poesen 2005; Hernandez et al. 2012). There are studies around the world that continue to work on the model to improve the model parameterization and application in different climate conditions and locations (Benavidez et al. 2018).

\section{Validation of model results}

One of the limitations of the RUSLE and perhaps many soil erosion models is the lack of data for validating the model outputs. Benavidez et al. (2018) indicated that validating the soil erosion rates estimated by the RUSLE is difficult because of the lack of easily available measured soil erosion records, especially in data-sparse regions. The same source revealed that out of the RUSLE applications reviewed for the study, approximately $30 \%$ only presented the validation of the modeled soil loss.

For validating model results, studies suggest that ground-truthing is an important method, as the areas of severe erosion threat can be verified for physical proof of soil loss incidence (Adornado and Yoshida 2010; Nontananandh and Changno 2012). The soil loss estimates can also be validated by comparing results with soil erosion studies of similar watersheds or larger-scale national or regional scale (Panagos et al. 2015; Nakil and Khire 2016).

In this study, due to a lack of measured data specific to the study area, the validity of the model outputs was compared with the results of other studies conducted in Ethiopia to check the validity of the outputs. In addition, field observations were carried out to identify severely erosion affected areas. The field visits were accompanied by color printed model output maps of soil erosion, sediment yield and retention maps to prove it on the ground. Similar approaches were used by Yesuph and Dagnew (2019).

\section{Results}

Soil erosion in the Lake Hawassa watershed Spatial variation of annual soil loss in the watershed

The soil loss estimation in each pixel ranged from 0 to $605 \mathrm{t} \mathrm{pixel}^{-1}$ (1 pixel $=0.09$ ha) (Fig. 4). The computed total annual soil loss from the watershed was 5,275,201 t $\left(37 \mathrm{t} \mathrm{ha}^{-1}\right.$ year $\left.^{-1}\right)$. As demonstrated in Fig. 4 and Table 4 , the annual soil loss was categorized into five erosion intensity classes. The result in the table indicated that $54.8 \%$ of the watershed was affected by very slight rates of soil erosion, while $15.7 \%$ and $9.9 \%$ of the watershed experience slight and moderate rates of soil loss, respectively. The remaining $19.6 \%$ of the watershed had severe and very severe soil loss rates (Table 4). The result also revealed that the majority of the soil loss $(83.1 \%)$ was contributed by a very small area (13.7\%) of the watershed which experiences high erosion rates per unit of area.

\section{Spatial variation of annual soil loss along slope classes}

The soil erosion rate in the Lake Hawassa watershed varies with slope. The result in Table 5 reveals that $83.4 \%$ of the watershed is situated on a slope $<15 \%$ and only $16.5 \%$ of the watershed is situated on the steeply sloping terrain (slope $>15 \%$ ). The result also indicated that areas with medium slop gradients have the highest contribution to the total annual soil loss compared to areas with lower and higher slope gradients. For instance, $67.8 \%$ of the soil loss was contributed by the slope ranging between 5 and $30 \%$. Besides, the result in the table revealed that the mean soil loss per unit of area (ha) increased linearly with increasing slope gradient. As shown in Table 5, the highest mean soil loss per unit of area $\left(201.4 \mathrm{t} \mathrm{ha}^{-1}\right.$ year $\left.^{-1}\right)$ was estimated on areas with slopes $>50 \%$ while the lowest $\left(10.6 \mathrm{t} \mathrm{ha}^{-1}\right.$ year $\left.^{-1}\right)$ was observed on areas with slopes $<5 \%$. 


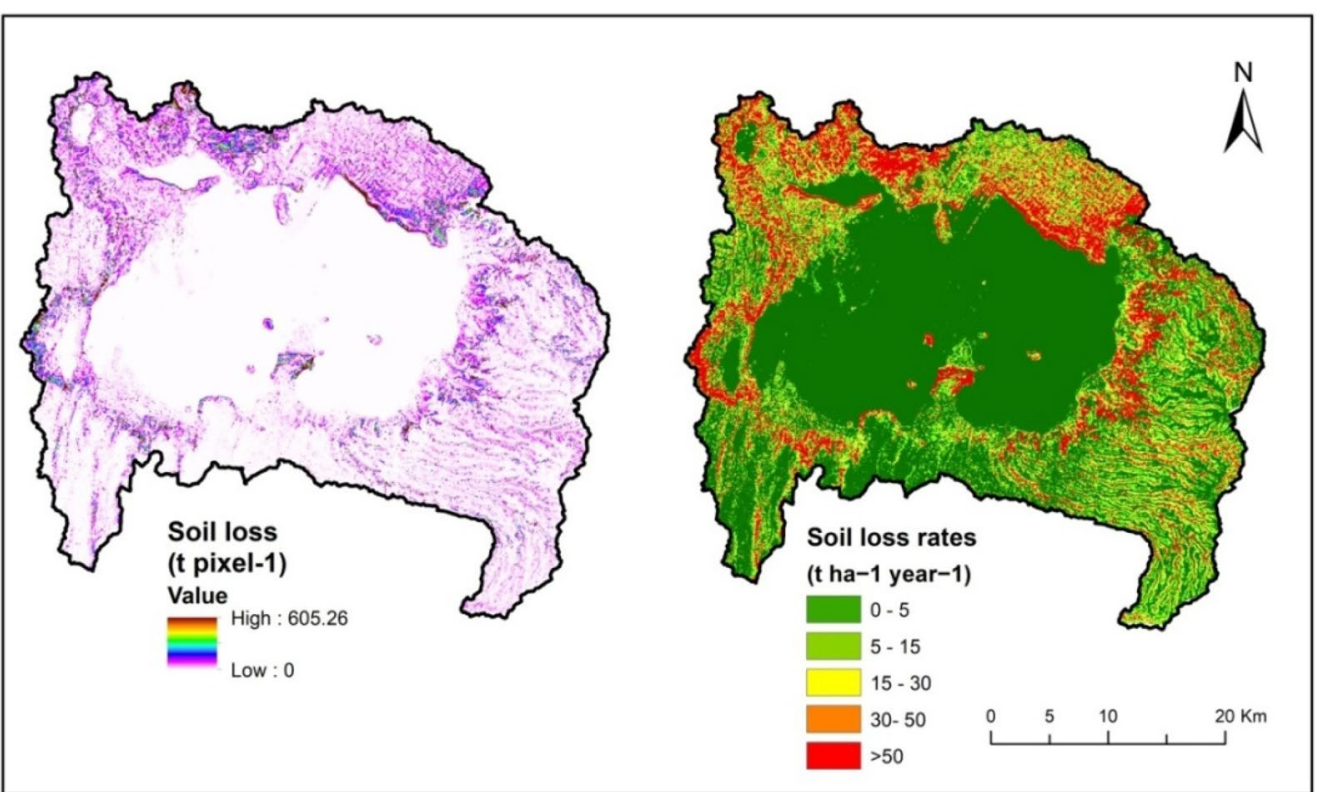

Fig. 4 Soil erosion rate in the Lake Hawassa watershed

Table 4 Severity classes, area coverage, magnitude and rates of annual soil erosion

\begin{tabular}{|c|c|c|c|c|c|}
\hline $\begin{array}{l}\text { Soil loss rates ( } \mathrm{t} \mathrm{ha}^{-} \\
{ }^{1} \text { year }^{-1} \text { ) }\end{array}$ & Severity classes ${ }^{\text {a }}$ & Area (ha) & Percent of total & $\begin{array}{l}\text { Estimated annual } \\
\text { loss }(t)\end{array}$ & $\begin{array}{l}\text { Percent of } \\
\text { total loss }\end{array}$ \\
\hline$<5$ & Very slight & $78,178.1$ & 54.8 & $80,425.5$ & 1.5 \\
\hline $5-15$ & Slight & $22,328.1$ & 15.7 & $189,940.6$ & 3.6 \\
\hline $15-30$ & Moderate & $14,124.7$ & 9.9 & $295,228.2$ & 5.6 \\
\hline $30-50$ & Severe & $8,440.8$ & 5.9 & $323,644.0$ & 6.1 \\
\hline$>50$ & Very sever & $19,589.3$ & 13.7 & $4,385,962.7$ & 83.1 \\
\hline Total & & 142,661 & 100.0 & $5,275,201.0$ & 100.0 \\
\hline
\end{tabular}

a This classification was made based on FAO (2006), Haregeweyn et al. (2017) and Yusuph and Dagnew (2019)

\section{Spatial variation of soil loss with LULC classes}

The soil erosion rate also revealed significant variations with LULC. According to the model results indicated in Table 6 , the highest contribution to the total soil loss was from cultivated land (41.9\%) which was followed by agroforestry (18\%). The lowest contribution to the total soil loss was from the built-up area (7.4\%) (disregarding lake and wetlands). However, the highest rate of erosion per unit of area was computed from bare land (599.6 $\mathrm{t} \mathrm{ha}^{-1}$ year $\left.^{-1}\right)$.

Table 5 Variation of annual soil erosion rates with slope classes

\begin{tabular}{|c|c|c|c|c|c|}
\hline \multirow[t]{2}{*}{ Slope class (\%) } & \multicolumn{2}{|l|}{ Area } & \multicolumn{3}{|c|}{ Estimated annual soil loss } \\
\hline & ha & $\%$ & t year $^{-1}$ & $\begin{array}{l}\text { Contribution to the total soil } \\
\text { loss }(\%)\end{array}$ & t ha $^{-1}$ year $^{-1}$ \\
\hline $0-5$ & $77,187.8$ & 54.1 & $816,977.2$ & 15.5 & 10.6 \\
\hline $5-15$ & $41,819.1$ & 29.3 & $2,025,774.5$ & 38.4 & 48.4 \\
\hline $15-30$ & $17,147.2$ & 12.01 & $1,551,541.5$ & 29.4 & 90.5 \\
\hline $30-50$ & $5,590.6$ & 3.9 & $696,352.8$ & 13.2 & 124.6 \\
\hline$>50$ & 916.3 & 0.6 & $184,554.8$ & 3.5 & 201.4 \\
\hline Total & $142,661.0$ & 100.0 & $5,275,200.9$ & 100.0 & 37.0 \\
\hline
\end{tabular}


Table 6 Variation of annual soil erosion rates with LULC types

\begin{tabular}{|c|c|c|c|c|c|}
\hline \multirow[t]{2}{*}{ LULC Class } & \multicolumn{2}{|l|}{ Area } & \multicolumn{3}{|c|}{ Estimated annual soil loss } \\
\hline & ha & $\%$ & ton year ${ }^{-1}$ & $\begin{array}{l}\text { Contribution to the total soil } \\
\text { loss (\%) }\end{array}$ & tha $^{-1}$ year $^{-1}$ \\
\hline Cultivated & $39,172.8$ & 27.5 & $2,209,089.0$ & 41.9 & 56.4 \\
\hline Agroforestry & $49,188.2$ & 34.5 & $952,106.0$ & 18.0 & 19.4 \\
\hline Bare land & 863.6 & 0.6 & $517,784.3$ & 9.8 & 599.6 \\
\hline Built-up & $5,637.3$ & 4.0 & $41,706.0$ & 0.8 & 7.4 \\
\hline Forest & $5,745.7$ & 4.0 & $150,472.0$ & 2.9 & 26.2 \\
\hline Grassland & $8,982.4$ & 6.3 & $133,821.0$ & 2.5 & 14.9 \\
\hline Lake & $9,512.5$ & 6.7 & 90.6 & 0.0 & 0.0 \\
\hline Shrubland & $9,667.7$ & 6.8 & $556,327.6$ & 10.5 & 57.5 \\
\hline Wetland & $4,376.9$ & 3.1 & 30.8 & 0.0 & 0.0 \\
\hline Woodland & $9,513.9$ & 6.7 & $713,773.8$ & 13.5 & 75.0 \\
\hline Total & $142,661.0$ & 100.0 & $5,275,201.1$ & 100.0 & 36.98 \\
\hline
\end{tabular}

\section{Sediment retention capacity of the Lake Hawassa watershed \\ Spatial variation of annual sediment retention in the watershed}

For estimating the amount of avoided soil erosion due to the existing LULC and management practices, the model uses a hypothetical scenario as a benchmark where all land is cleared to bare soil. Then, it calculates the amount of retained sediment based on the difference between the sediment export from the watershed under bare soil and the sediment export from the watershed under the existing LULC.

As indicated in Fig. 5, the sediment retention potential of the watershed was in a range of $0-11,231.7 \mathrm{t}_{\text {pixel }}^{-1}$.
Due to the existing LULC and management practices, a total of $18,646,116 \mathrm{t} \mathrm{year}^{-1}\left(130.7 \mathrm{t} \mathrm{ha}^{-1}\right.$ year $\left.^{-1}\right)$ of sediment was retained in the watershed. As it is indicated in Table 7 , the annual average sediment retention capacity of the watershed was grouped into five sediment retention capacity levels. The result revealed that $51.4 \%$ of the watershed had very low sediment retention capacity, while $16.7 \%$ and $25 \%$ of the watershed had low and moderate sediment retention capacities, respectively. Only $7 \%$ of the watershed had high and very high sediment retention capacity. Also, the result revealed that $84.7 \%$ of the total sediment was retained by only $32 \%$ of the watershed (Fig. 5 and Table 7).

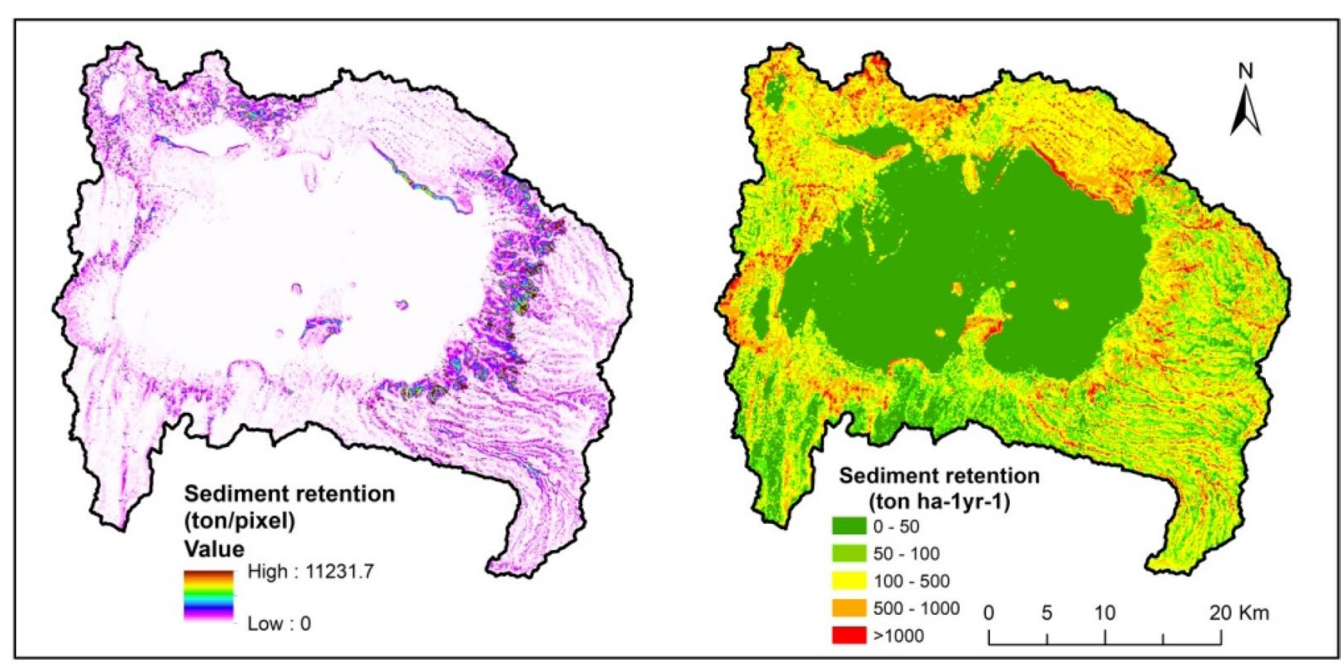

Fig. 5 Sediment retention rate in the Lake Hawassa watershed 
Table 7 Annual sediment retention levels, rates, and area coverage

\begin{tabular}{llcccc}
\hline $\begin{array}{l}\text { Sediment retained (t } \\
\mathbf{h a}^{-\mathbf{1}} \text { year }{ }^{-1} \text { ) }\end{array}$ & Retention levels & Area (ha) & \% of the total area & $\begin{array}{l}\text { Estimated annual Sediment } \\
\text { retention }(\mathbf{t})\end{array}$ & $\begin{array}{l}\text { \% of the } \\
\text { total } \\
\text { retention }\end{array}$ \\
\hline $0-50$ & Very low & $73,377.2$ & 51.4 & $734,325.4$ & 3.9 \\
$50-100$ & Low & $23,768.9$ & 16.7 & $2,118,433.6$ & 11.4 \\
$100-500$ & Moderate & $35,619.5$ & 25.0 & $6,906,696.0$ & 37.0 \\
$500-1000$ & High & $8,515.5$ & 6.0 & $5,699,354.4$ & 30.6 \\
$>1000$ & Very high & $1,379.9$ & 1.0 & $3,187,306.6$ & 17.1 \\
Total & & $142,661.0$ & 100 & $18,646,115.97$ & 100 \\
\hline
\end{tabular}

\section{Spatial variation of sediment retention along slope classes}

The spatial distribution of the retained sediment varies with slope gradients. As demonstrated in Table 8, the contribution to total watershed's sediment retention was higher in areas with slope range of $15-30 \%$ followed by $5-15 \%$ and $30-50 \%$. Overall, $86 \%$ of the sediment was retained by areas within the slope ranges of $5-50 \%$. However, the sediment retention per unit area (ha) revealed an increasing trend with increasing slope gradients, being the highest $\left(1,378.6 \mathrm{t} \mathrm{ha}^{-1}\right.$ year $\left.^{-1}\right)$ on slopes $>50 \%$.

\section{Spatial variation of sediment retention with LULC classes}

Similar to the variations observed in soil loss, the spatial distribution of the retained sediment varied with LULC types. As depicted in Table 9; agroforestry, forest, and woodland with their respective $36.5 \%, 28.2 \%$, and $13.9 \%$ contribution to the total sediment retention; had the highest sediment retention capacity while bare land $(0.3 \%)$ and built-up (0.6\%) (disregarding lake and wetlands) had the lowest retention capacity. However, high sediment retention per unit of area (ha) were estimated from the forest $\left(915 \mathrm{t} \mathrm{ha}^{-1}\right.$ year $\left.^{-1}\right)$, woodland (273 t ha $\left.\mathrm{year}^{-1}\right)$, shrubland (143 t ha ${ }^{-1}$ year $\left.^{-1}\right)$, and agroforestry $\left(138.2 \mathrm{t} \mathrm{ha}^{-1}\right.$ year $^{-1}$ ) while lower sediment retention was computed from built-up $\left(20.1 \mathrm{t} \mathrm{ha}^{-1}\right.$ year $\left.^{-1}\right)$, grassland $\left(55.6 \mathrm{t} \mathrm{ha}^{-1}\right.$ year $\left.^{-1}\right)$ and bare land $\left(62.1 \mathrm{tha}^{-1}\right.$ year $\left.^{-1}\right)$.

\section{Sediment export in the Lake Hawassa watershed} Spatial variation of annual sediment export in the watershed Exported sediment is the sediment beyond retention capacity of the vegetative cover and management practices that has the potential to reach the nearby streams. It is the sediment amount that can be compared to any observed sediment loading at the outlet of a watershed. For estimating the sediment export in each cell, the model first computes the amount of eroded sediment, then the sediment delivery ratio (SDR), which is the amount of soil loss that actually reaches the nearby streams and outlet of the watershed.

The result revealed that the computed total annual sediment export from the watershed was 226,690.3 tons (1.6 $\mathrm{t} \mathrm{ha}^{-1}$ year $\left.^{-1}\right)$ (Table 10). The sediment export from each pixel in the watershed was in a range of 0-239.9 $\mathrm{t} \mathrm{pixel}^{-1}$ (Fig. 6). Besides, the result in Table 10 shows that $85 \%$ of the watershed had a sediment export $<1 \mathrm{t} \mathrm{ha}^{-1}$ year $^{-1}$, contributing only $8.1 \%$ of the total sediment export. Whereas, $7.6 \%$ of the watershed had a sediment export of $1-5 \mathrm{t} \mathrm{ha}^{-1}$ year $^{-1}$ while supplying $18.7 \%$ of the total sediment. A sediment export $>5 \mathrm{t} \mathrm{ha}^{-1}$ year $^{-1}$ was estimated from only $7.4 \%$ of the watershed which contributed $73.2 \%$ of the total sediment export.

Table 8 Variation of annual sediment retention rates with slope classes

\begin{tabular}{|c|c|c|c|c|c|}
\hline \multirow[t]{2}{*}{ Slope class (\%) } & \multicolumn{2}{|l|}{ Area } & \multicolumn{3}{|c|}{ Estimated annual Sediment retention } \\
\hline & ha & $\%$ & t year $^{-1}$ & $\begin{array}{l}\text { Contribution to total sediment } \\
\text { retention (\%) }\end{array}$ & tha $^{-1}$ year $^{-1}$ \\
\hline $0-5$ & $77,187.8$ & 54.1 & $1,230,643.7$ & 6.6 & 15.9 \\
\hline $5-15$ & $41,819.1$ & 29.3 & $5,407,373.6$ & 29.0 & 129.3 \\
\hline $15-30$ & $17,147.2$ & 12.0 & $6,115,926.0$ & 32.8 & 356.3 \\
\hline $30-50$ & $5,590.6$ & 3.9 & $4,642,882.9$ & 24.9 & 830.5 \\
\hline$>50$ & 916.3 & 0.6 & $1,249,289.8$ & 6.8 & 1378.6 \\
\hline Total & $142,661.0$ & 100.0 & $18,646,116.0$ & 100 & \\
\hline
\end{tabular}


Table 9 Sediment retention by LULC types

\begin{tabular}{|c|c|c|c|c|c|}
\hline \multirow[t]{2}{*}{ LULC Class } & \multicolumn{2}{|l|}{ Area } & \multicolumn{3}{|c|}{ Estimated annual sediment retention } \\
\hline & ha & $\%$ & $\mathrm{t}_{\text {year }}$-1 $^{-1}$ & $\begin{array}{l}\text { Contribution to the total sediment } \\
\text { retention (\%) }\end{array}$ & tha ${ }^{-1}$ year $^{-1}$ \\
\hline Cultivated & $39,172.80$ & 27.5 & $1,939,196.1$ & 10.4 & 49.4 \\
\hline Agroforestry & $49,188.20$ & 34.5 & $6,805,832.3$ & 36.5 & 138.2 \\
\hline Bare land & 863.6 & 0.6 & $55,938.3$ & 0.3 & 62.1 \\
\hline Built-up & $5,637.30$ & 4.0 & $111,876.7$ & 0.6 & 20.1 \\
\hline Forest & $5,745.70$ & 4.0 & $5,258,204.7$ & 28.2 & 915.0 \\
\hline Grassland & $8,982.40$ & 6.3 & $503,445.1$ & 2.7 & 55.6 \\
\hline Lake & $9,512.50$ & 6.7 & 0 & 0.0 & 0.1 \\
\hline Shrubland & $9,667.70$ & 6.8 & $1,379,812.6$ & 7.4 & 143.0 \\
\hline Wetland & $4,376.90$ & 3.1 & 0 & 0.0 & 1.1 \\
\hline Woodland & $9,513.90$ & 6.7 & $2,591,810.1$ & 13.9 & 273.2 \\
\hline Total & $142,661.00$ & 100.0 & $18,646,116.0$ & 100 & 130.7 \\
\hline
\end{tabular}

Table 10 Annual sediment export rates, magnitude and area coverage

\begin{tabular}{|c|c|c|c|c|c|}
\hline $\begin{array}{l}\text { Exported sediment }(\mathrm{t} \\
\left.\mathrm{ha}^{-1} \text { year }^{-1}\right)\end{array}$ & Export level & Area (ha) & $\begin{array}{l}\text { Percent of the total } \\
\text { area }\end{array}$ & $\begin{array}{l}\text { Estimated annual sediment } \\
\text { export }\left(t \text { year }^{-1}\right)\end{array}$ & $\begin{array}{l}\text { Percent of the } \\
\text { total export }\end{array}$ \\
\hline 0 & Low & $121,219.0$ & 85.0 & $18,267.5$ & 8.1 \\
\hline $1-5$ & Moderate & $10,864.8$ & 7.6 & $42,433.5$ & 18.7 \\
\hline 5 & High & $10,577.2$ & 7.4 & $165,989.3$ & 73.2 \\
\hline Total & & $142,661.0$ & 100.0 & $226,690.3$ & 100.0 \\
\hline
\end{tabular}

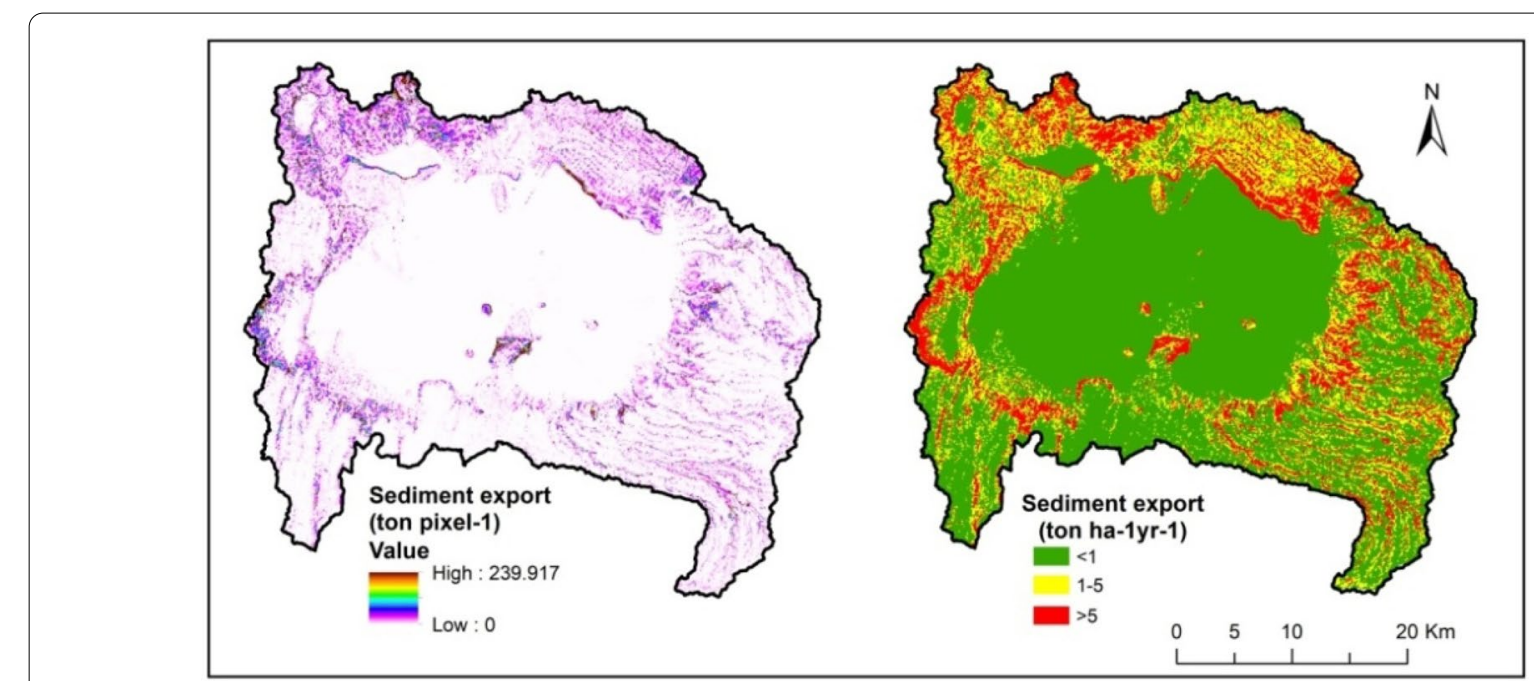

Fig. 6 Sediment export rate in the Lake Hawassa watershed

\section{Spatial variation of sediment export along slope classes}

There was variation in the spatial distribution of sediment export with slope. The contribution to the total sediment export was higher for the medium slope areas. For instance, about $70 \%$ of the sediment exported to the nearby water bodies was contributed by areas with slopes ranging between 5 and $30 \%$ (Table 11 ). Only $15.3 \%$ of the exported sediment 
was contributed by areas with slopes below 5\%, with a similar proportion of sediment was contributed by slopes $>30 \%$. However, it is indicated in Table 11 that the annual mean sediment export per hectare increased linearly with increasing slope gradients. Areas with higher slope gradients contributed greater exported sediment per hectare than areas with lower slope gradients. For example, the highest mean sediment export per hectare was estimated from areas with slopes $>50 \%$ with the lowest computed from areas with slopes $<5 \%$.

\section{Spatial variation of sediment export with LULC classes}

Similar to the result observed in the spatial distribution of soil loss, variation of sediment export was observed with different LULC classes. From the total sediment that reaches the surrounding water bodies, the highest contribution was from cultivated land (40.7\%) (Table 12). However, the highest sediment export per unit of area (ha) was observed from bare land.

\section{The environmental implications of soil erosion} and sediment yield

Lake Hawassa is located in a closed watershed. The lake is situated at the lowest elevation in the watershed and it is the end receiver of runoff and sediment from the whole watershed. It was indicated in "Sediment export in the Lake Hawassa watershed" section that the total annual sediment export from the watershed that joins the lake was 226,690.3 $\mathrm{t}\left(1.6 \mathrm{t} \mathrm{ha}^{-1}\right.$ year $\left.^{-1}\right)$. The accumulation of such an amount of sediment in the lake has many environmental repercussions. One of the effects was the dry-out of Lake Cheleleka, a small lake that is located upstream of Lake Hawassa (Fig. 7). Also, the increase in the surface area and the rise in the water level of Lake Hawassa are the other effects that are likely or partly related to such sediment accumulation (Figs. 8 and 9). Lake Cheleleka with a surface area of 570 ha in the 1992 LULC map was not identified in the 2017 LULC map, indicating the complete dried-out of the lake (Fig. 7). Besides, the surface area of Lake Hawassa which was 9,249 ha in 1992 increased

Table 11 Variation of annual sediment export rates with slope classes

\begin{tabular}{|c|c|c|c|c|c|}
\hline \multirow[t]{2}{*}{ Slope class (\%) } & \multicolumn{2}{|l|}{ Area } & \multicolumn{3}{|c|}{ Estimated annual sediment export } \\
\hline & ha & $\%$ & t year $^{-1}$ & $\begin{array}{l}\text { Contribution to the total } \\
\text { sediment export (\%) }\end{array}$ & tha $^{-1}$ year $^{-1}$ \\
\hline $0-5$ & $77,187.8$ & 54.1 & $34,675.58$ & 15.3 & 0.5 \\
\hline $5-15$ & $41,819.1$ & 29.3 & $90,087.59$ & 39.7 & 2.2 \\
\hline $15-30$ & $17,147.2$ & 12.01 & $67,754.61$ & 29.9 & 4.0 \\
\hline $30-50$ & $5,590.6$ & 3.9 & $28,393.01$ & 12.5 & 5.1 \\
\hline$>50$ & 916.3 & 0.6 & $5,779.56$ & 2.5 & 6.3 \\
\hline Total & $142,661.0$ & 100.0 & $226,690.36$ & 100 & 1.6 \\
\hline
\end{tabular}

Table 12 Sediment export by LULC types

\begin{tabular}{|c|c|c|c|c|c|}
\hline \multirow[t]{2}{*}{ LULC class } & \multicolumn{2}{|l|}{ Area } & \multicolumn{3}{|c|}{ Estimated annual sediment export } \\
\hline & ha & $\%$ & t year $^{-1}$ & $\begin{array}{l}\text { Contribution to the total sediment } \\
\text { export (\%) }\end{array}$ & $\mathrm{Tha}^{-1}$ year $^{-1}$ \\
\hline Cultivated & $39,172.8$ & 27.5 & $92,263.0$ & 40.7 & 2.4 \\
\hline Agroforestry & $49,188.2$ & 34.5 & $34,683.6$ & 15.3 & 0.7 \\
\hline Bareland & 863.6 & 0.6 & $28,789.7$ & 12.7 & 33.2 \\
\hline Built-up & $5,637.3$ & 4.0 & $2,040.2$ & 0.9 & 0.4 \\
\hline Forest & $5,745.7$ & 4.0 & $5,213.9$ & 2.3 & 0.9 \\
\hline Grassland & $8,982.4$ & 6.3 & $5,440.6$ & 2.4 & 0.6 \\
\hline Lake & $9,512.5$ & 6.7 & - & 0.0 & 0.0 \\
\hline Shrubland & $9,667.7$ & 6.8 & $26,522.8$ & 11.7 & 2.7 \\
\hline Wetland & $4,376.9$ & 3.1 & - & 0.0 & 0.0 \\
\hline Woodland & $9,513.9$ & 6.7 & $31,736.7$ & 14.0 & 3.3 \\
\hline Total & $142,661.0$ & 100.0 & $226,690.4$ & 100 & 1.6 \\
\hline
\end{tabular}




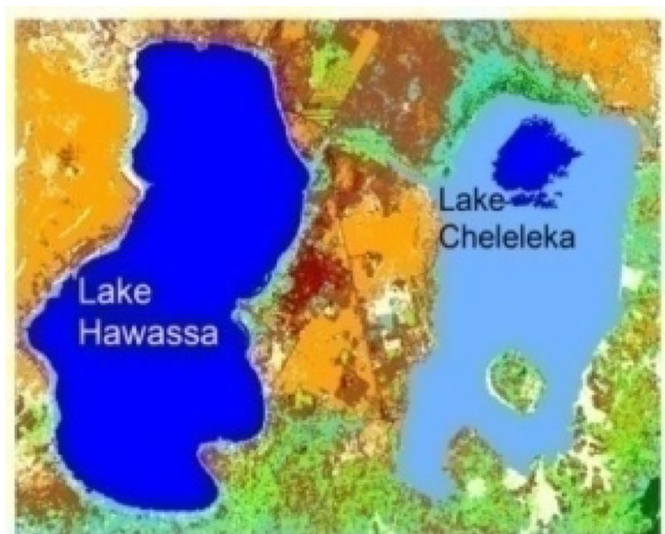

1992

\section{Legend}
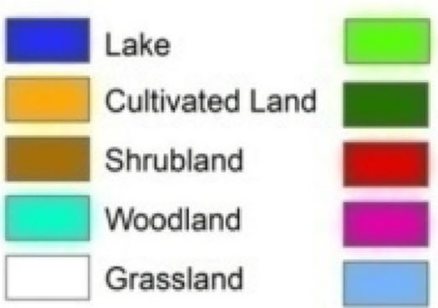

Agroforestry

Forest

Built-up

Bareland

Wetland
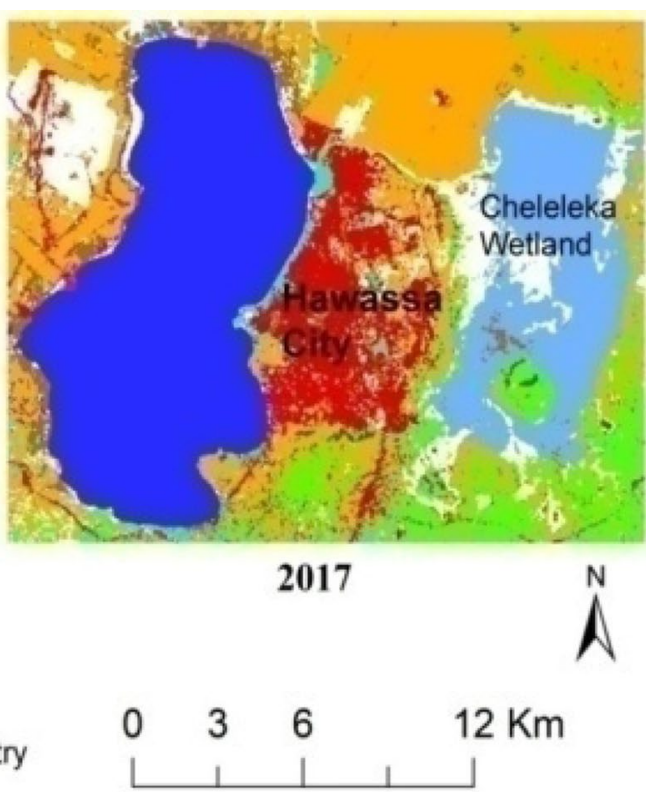

Fig. 7 Lake Cheleleka in 1992 and 2017

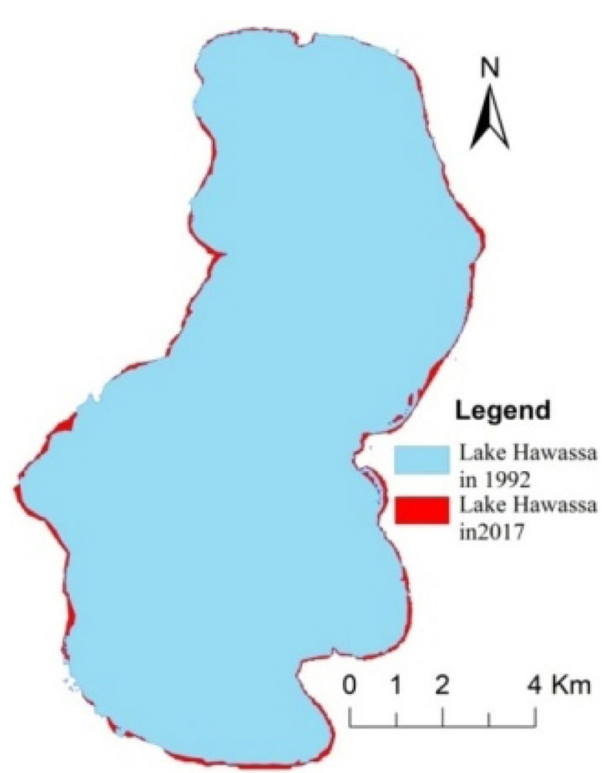

Fig. 8 Surface area of the Lake Hawassa in 1992 and 2017

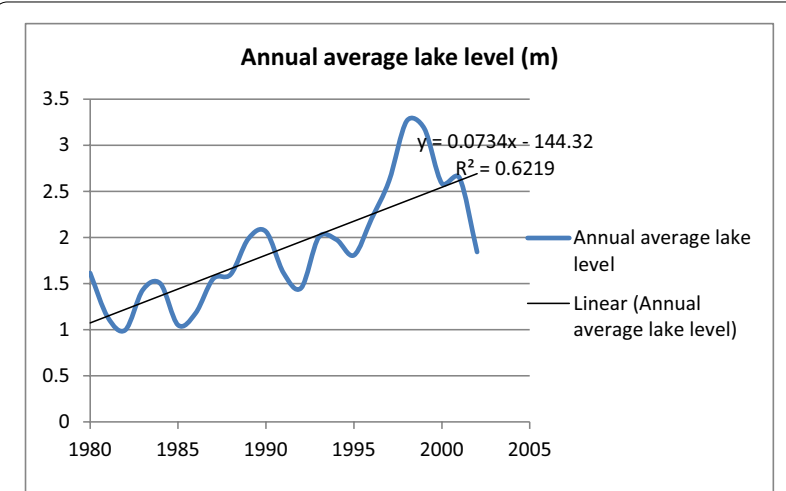

Fig. 9 Water level of Lake Hawassa

to 9481 ha in 2017, signifying the accumulation of sediment in the lake and flow-out of the water to the surrounding areas (Fig. 8). A personal experience of the area indicates that the rise in the lake level and the resulting flooding have been the major environmental concerns threatening the nearby Hawassa city in the last few decades. 


\section{Discussion}

Soil erosion and sediment retention and export in the Lake Hawassa watershed

Soil erosion

Understanding the level of soil erosion, sediment export, and soil retention are important for science-based sustainable management of natural resources in a watershed. The study found that the average rate of soil loss from the watershed was $37 \mathrm{t} \mathrm{ha}^{-1}$ year $^{-1}$. The estimated soil loss value is higher compared to the soil formation rates of different places in Ethiopia, which were estimated to be in a range of 2-22 $\mathrm{t} \mathrm{ha}^{-1}$ year $^{-1}$ (Hurni 1983). Besides, the value is higher compared to the soil loss tolerance limit in Ethiopia, which was suggested by Hurni (1986) to be in a range of $2-18 \mathrm{t} \mathrm{ha}^{-1}$ year $^{-1}$ on agricultural lands, and which was estimated by Morgan (1995) to be $10 \mathrm{t} \mathrm{ha}^{-1}$ year $^{-1}$. Moreover, the value is higher than the soil loss rate that can be reversed within a time span of 50 to 100 years. Kouli et al. (2009) reported that an erosion rate which is above $10 \mathrm{t} \mathrm{ha}^{-1}$ year $^{-1}$ will not be reversed within a period of 50 to 100 years.

However, the computed erosion rate in the watershed is less than the highest rates of erosion in Ethiopia which were reported by Zeleke (2000) in northwestern highlands of Ethiopia (243 t ha ${ }^{-1}$ year $^{-1}$ ), Sahle et al. (2019) in the Wabe River catchment (165 $\mathrm{t} \mathrm{ha}^{-1}$ year $^{-1}$ ), and Haregeweyn et al. (2015) in Anjeni (110 t ha ${ }^{-1}$ year $\left.^{-1}\right)$ and Chemoga (102 $\mathrm{t} \mathrm{ha}^{-1}$ year $^{-1}$ ) watersheds in Ethiopia. On the other hand, the value is greater than the rate reported by Haregeweyn et al. (2015) who reported the average soil erosion rate in Ethiopia to be $29.9 \mathrm{t} \mathrm{ha}^{-1}$ year $^{-1}$.

Overall, compared to the soil loss estimated values in this study, the figures in the literature have disparity and inconsistency. Such disparity may arise from the use of different methods and the variations in the biophysical environment and management practices. Nevertheless, the estimated value and spatial distribution of the estimated soil loss were comparable to what is observed in the field and to that reported by SCRP (1996) (35 t ha ${ }^{-1}$ year $^{-1}$ ) and Yesuph and Dagne (2019) (37 $\mathrm{t} \mathrm{ha}^{-1}$ year $^{-1}$ ) in the northern Ethiopia, where high erosion rates were reported to exist.

Concerning the spatial distribution of the estimated soil loss, the study revealed that about $18 \%$ of the watershed had severe and very severe soil loss rates, contributing $88 \%$ of the soil loss. Also, the study indicated large part of the watershed had slight and very slight soil loss rates. This implies that most of the total soil loss was contributed by a small part of the watershed which experienced high erosion rates. Hence, there is a need to implement targeted soil and water conservation measures of various types to ensure the sustainability of the watershed resources. The soil loss map (Fig. 4) also revealed that the extent of soil loss is the highest in the upper reaches of the watershed. This could be due to the expansion of agricultural activities into marginal steep slope areas which cleared large areas of forest, woodland and shrubland, and exposed the soil for the direct forces of raindrops.

From a slope perspective, the study revealed a considerable effect of slope gradient on the rate of soil erosion. Although higher soil loss per unit of area was identified on the highest slope gradients, greater contribution to the total soil loss was estimated from medium-ranging slopes (slopes with 5-30\%). This is mainly because of the smaller proportion of the watershed with very steep slope gradients. For instance, only $4.5 \%$ of the watershed exists on slopes $>30 \%$. Hence, the contribution from such steep slope gradients to the total soil loss was small (only $16.7 \%$ of the total soil loss). On the other hand, part of the watershed with a 5-30\% slope gradient covers a significant proportion of the watershed $(41.3 \%)$ and contributed $67.8 \%$ of the total soil loss. This is mainly because this part of the watershed was accessible to agricultural practices and contains relatively optimal slope gradients that can induce erosion. Hence, apart from slope gradient, the proportion of area with a relatively higher slope gradient is the major factor that determines the rate of soil loss in the area. Therefore, priority should be given not only for steep slopes but also for medium slopes during stabilizing slopes using various soil and water conservation structures for controlling soil erosion.

In connection with LULC, the study indicated a considerable effect of the type of LULC on the extent of soil erosion in the Lake Hawassa watershed. The highest contribution to the total soil loss in the watershed was from cultivated land while the highest rate of soil loss per hectare was observed from bare land. It appears that the higher soil loss from cultivated land was related to the intensive farming of large area on higher slopes of the watershed due to high population pressure. This caused the removal of the natural vegetative cover that exposed the soil to direct forces of raindrops and running water and enhanced the soil erosion rate in the watershed. In this regard, our result is comparable to the results of similar studies which were conducted in other catchments which found cropland has the highest contribution to a watershed's soil loss (Sharma et al. 2011; Yesuph and Dagnew 2019; Aneseyee 2020). Besides, although the study revealed a higher rate of soil loss per hectare on bare land, its contribution to the total soil loss was minimal because of its small area coverage in the watershed.

\section{Sediment export}

The study reported that the sediment export to the water bodies in the watershed was $1.6 \mathrm{t} \mathrm{ha}^{-1}$ year $^{-1}$. The result 
is comparable to other sediment yield estimations in Ethiopia. For instance, Haregeweyn et al. (2012) estimated a 2 to $19 \mathrm{t} \mathrm{ha}^{-1}$ year $^{-1}$ of sediment export from 14 microdam watersheds in northern Ethiopia. Sahle et al. (2019) also identified a sediment export of $0-33 \mathrm{t} \mathrm{ha}^{-1}$ year $^{-1}$ from the Wabe River catchment of the Gibe basin. The estimated sediment export value was comparatively low to the reported figures. This is likely due to the remarkable difference in the climate, elevation, terrain, drainage density, soil types and conditions, geology, sizes of the watershed, and LULC between the study areas. However, field observations indicate that mass of soil materials that were removed from steep slopes of the watershed have been accumulated in downstream areas. Such exported sediment created problems of lake sedimentation, pollution of water bodies, and sediment deposition on the active agricultural lands.

The spatial distribution of the sediment export along the slope and LULC classes was in line with the results observed in the spatial distribution of the soil loss. Similar to the values observed in the soil loss, the sediment export per unit of area increased linearly with increasing slope gradient, with the highest values observed on very steep slopes. The contribution to the total sediment export from the watershed was also proportional to the amount of the estimated soil loss. The highest sediment export was observed from the slopes ranging between 5 and $30 \%$. Areas within this slope class contributed 69.6\% of the total sediment export. This is mainly due to the relatively increasing slope gradient and the fact that a significant part $(41.3 \%)$ of the watershed is located within this slope category. Although $54.1 \%$ of the watershed is situated within a slope range $<5 \%$, the contribution to the total soil loss and sediment export from this slope class was only $15.5 \%$ and $15.3 \%$, respectively. This is mainly due to the plain nature of the area that made it less liable to running water and erosion. In addition, the sediment contribution of the area located on slopes $>30 \%$ is only $15 \%$ of the total sediment export because of the reason that a small part $(4.5 \%)$ of the watershed was located within this slope category.

The estimated sediment export along the LULC classes was also in line with the results observed in the spatial distribution of the soil loss. The result revealed that the highest contribution to the total sediment export comes from cultivated lands. The result conforms to the findings of Haregeweyn et al. (2015) who found higher sediment export from cultivated lands. This is likely associated with the cultivation of steep slopes, intensive plowing and mono-cropping practices, and poor land management activities. Hence, the result gives a reason to suggest the need for promoting sustainable land management practices on steep slopes in the watershed.

\section{Sediment retention}

The estimation of the sediment retention capacity of the watershed shows that large volumes of sediment, which could impose great environmental problems on the downstream lake ecosystem, was maintained because of the existing vegetative cover and management practices in the watershed. The estimated average annual sediment retention was $130.7 \mathrm{t} \mathrm{ha}^{-1} \mathrm{year}^{-1}$. This value is greater than the rate of soil loss $\left(37 \mathrm{t} \mathrm{ha}^{-1}\right.$ year $\left.^{-1}\right)$ and sediment export $\left(1.6 \mathrm{t} \mathrm{ha}^{-1}\right.$ year $\left.^{-1}\right)$ in the watershed. This means that the watershed has high sediment yield potential but a large part of it was retained by the existing vegetative cover. Besides, a high level of sediment was retained by slopes ranging between 5 and $50 \%$, where high soil loss and sediment export potential were estimated. This implies that much of the sediment retention was observed on high sediment yield potential areas; indicating the requirements for protecting, retaining, and enhancing the existing vegetation cover and targeted management practices on this slope range to sustain and enhance the sediment retention capacity of the watershed. Moreover, the estimated sediment retention along the LULC classes revealed that vegetation-covered LULCs such as forest land, woodland, shrubland, and agroforestry had the highest sediment retention capacity. It appears that the remnant vegetation and expanding agroforestry practices may have supported the protection of such significant volumes of soil from being further exported to the water bodies.

\section{Environmental implications of soil erosion and sediment export}

The study revealed that the expansion of cultivation on higher slopes combined with meager land management practices is continuing to erode the top fertile soil and causing sediment deposition in the water bodies. It appears that the rise in the water level and expansion of the surface area of Lake Hawassa are likely related to such accumulation of sediment. In support of this, studies indicate that the horizontal expansion of Lake Hawassa is resulting in flooding of lakeshore areas, damaging of properties, and displacement of people due to the rising lake level (Belete 2013; Degife et al. 2019). It has to be noted that the pressure on natural resources will continue to increase tremendously as the watershed is being occupied by more people, settlements, farms, industries, and an increasing population. For instance, according to the estimate by the Federal Government of Ethiopia, Ministry of Water, Irrigation and Energy (MoWIE) and the Rift valley Lakes Basin Master Plan Studies the population of watershed increased from 839,585 in 2007 to $2,491,295$ in 2020 with an annual population growth rate of over $4 \%$. This implies that there is a highly increasing 
population in the area and this is a clear indication that the watershed will continue to be under pressure in the coming years with such population increase. Hence, the sustainability of sensitive ecosystems such as lakes, wetlands and related fauna, and flora will continue to be under threat unless appropriate and integrated interventions are implemented.

\section{Management and policy implications}

The study revealed that anthropogenic activities affected the state of erosion and sediment yield in the watershed. In line with this result, a study by Bewket (2003) in the Chemoga watershed indicated that loss of vegetation and the consequent soil erosion in upstream areas resulted in agricultural land degradation, sedimentation, and pollution of water bodies and increased flood flows in downstream areas. Hence, as it is suggested by De Graff (1996) and Bewket (2003), well-coordinated conservation measures are required to avert the problem. The measures may include afforestation, reforestation, soil and water conservation, and limiting further expansion of bare and degraded lands. The conservation activities measures should be designed to tackle the worst cases which cause greater soil losses. For the measures to be effective, active participation of the community during planning and implementation is mandatory. As Sharma (1999) and Bewket and Sterk (2002) suggested, the participation of the local people is at the center of resource conservation. People are also required to be provided with options of conservation technologies and be allowed to opt on what is suitable for the biophysical and socioeconomic situation of their landscape. Without the active participation of people, conservation activities mostly end up with a failure (Bewket 2003). Moreover, the delivered technologies should also address people's priorities and be able to provide perceivable, quick, and direct benefits that address the issues of food security and poverty. As Blaikie (2016) confirmed, resource degradation is a cause, sign, and outcome of poverty. Without addressing rural poverty, sustainable management of natural resources is very difficult. Hence, providing farmers with economically rewarding conservation activities is important. Finally, the study indicated that there is high population growth in the watershed while the watershed resources are degrading critically. Although there is a policy in the country for the control of rapid population growth since 1994, little or no success has been achieved in this regard. Thus, there is a need to revise the existing population policy and strategies and enhance political commitment to control the ever-increasing population number against the economic growth and deteriorating natural resources.

\section{Conclusion}

Soil erosion and sediment yield are critical environmental problems in the Lake Hawassa watershed. This study not only mapped and quantified the spatial distribution of the annual soil erosion and sediment yield and retention capacity of the watershed but also identified their downstream environmental and management implications.

The study revealed much of the soil erosion and sediment export were contributed by cultivated lands and higher slopping areas in the watershed. This reveals that the soil erosion and sediment yield in the watershed were mainly induced by human activities through the cultivation of higher slopes. In fact, it is not disregarded that other factors such as soil type, rainfall, and vegetation also have a great influence on the rate of soil erosion and sediment yield in the watershed.

The estimated average annual soil loss was $37 \mathrm{t} \mathrm{ha}^{-1}$ year $^{-1}$ and was found to be higher than the soil loss tolerance limits for Ethiopian highlands. In addition, the estimated exported sediment to the nearby water bodies was $1.6 \mathrm{t} \mathrm{ha}^{-1}$ year $^{-1}$, which was generally reasonable compared to the reported figures in Ethiopia and to what is observable in the field. Greater contributions to the total soil loss and sediment export were observed from cultivated lands and slope gradients ranging between 5 and 30\% while the highest soil loss and sediment export per hectare was estimated from bare lands and higher slope areas in the watershed. Although, the greater part of the watershed has a low contribution to the total soil loss and sediment export, extreme and very extreme soil erosion and sediment export were observed in parts of the watershed with scanty vegetative cover, poor conservation practices, cultivated and bare lands, steep slopes and mountainous areas.

Large volumes of soil which had the potential to be exported to the water bodies in the watershed were also retained due to the existing vegetative cover and management practices. The estimated average annual sediment retention was $130.7 \mathrm{t} \mathrm{ha}^{-1}$ year $^{-1}$, which was higher than the rate of soil loss and sediment export in the watershed. The study showed that a very small part of the watershed retained the great majority of the sediment that has the potential to be exported to the water bodies. Areas with a slope range of $5-50 \%$ and vegetated LULCs such as forest land, woodland, shrubland, and agroforestry had the highest contribution to the retained sediment.

The study signifies that the soil erosion and sediment export from the watershed had led to lake surface expansion, lake level rise, and dry-out of a small lake. The information obtained from the estimated soil loss and sediment export and retention was found to be useful for implementing sustainable lake watershed management in general and planning soil conservation 
measures in particular. The study demonstrated that InVEST model is useful to better estimate soil loss and sediment yield and retention in data-sparse watersheds like Lake Hawassa. The result helps to identify hotspot areas and prioritize areas for effective planning of sustainable lake watershed management. The study also gives a lesson on how to ease and systematize watershed planning and management and prioritize intervention areas for decision-making through the use of modeling, GIS, and remote sensing tools. Finally, for effective conservation of watershed resources, the study recommends that there is a need to plan for sustainable lake watershed management through effective soil and water conservation activities with the active participation of the local people.

\section{Recommendations for future research}

The model represents rill and inter-rill erosion processes only and has a limitation of estimating gully erosion. This limitation suggests the need for further studies using other possible modeling approaches to identify and measure gullies in the watershed to improve the accuracy of soil loss and sediment yield estimations for better planning and management in the future. In addition, given the simplicity of the model and the small number of input parameters, it is likely that outputs are very sensitive to most input parameters. However, sensitivity analysis was not carried out to identify the most sensitive input parameters that may help selective and targeted interventions. Hence, further studies are recommended to conduct sensitivity analyses to investigate how the confidence intervals in input parameters influence the study outputs and identify the most sensitive parameters.

\section{Acknowledgements}

The first author would like to thank Addis Ababa University Thematic Area Research Fund for supporting the cost of data collection.

\section{Authors' contributions}

$\mathrm{AD}$ (main author) collected, analyzed, and interpreted the data and wrote the manuscript. HW and SG edited, commented, and suggested ideas in the manuscript preparation process. All authors read and approved the final manuscript.

\section{Availability of data and materials}

All data and materials used in the study are presented in the main paper.

\section{Declarations}

Ethics approval and consent to participate

Not applicable.

\section{Consent for publication}

Not applicable.

\section{Competing interests}

The authors declare that they have no competing interests.

\section{Author details}

${ }^{1}$ Environmental Planning Program, Ethiopian Institute of Architecture, Building Construction, and City Development, Addis Ababa University (AAU), P.O.Box: 518, Addis Ababa, Ethiopia. ${ }^{2}$ Department of Geography and Environmental Studies, Dilla University, Dilla, Ethiopia. ${ }^{3}$ Ethiopian Institute of Architecture, Building Construction and City Development (EiABC), Addis Ababa University (AAU), P.O.Box: 518, Addis Ababa, Ethiopia. ${ }^{4} \mathrm{AAU}$ and DG of Information Network Security Agency (INSA), Federal Government of Ethiopia, Addis Ababa, Ethiopia.

Received: 21 January 2021 Accepted: 23 April 2021

Published online: 03 May 2021

\section{References}

Adornado HA, Yoshida M (2010) Assessing the adverse impacts of climate change: a case study in the Philippines. J Develop Sustain Agricu 5(1):141-146

Adornado HA, Yoshida M, Apolinares HA (2009) Erosion vulnerability assessment in REINA, Quezon Province, Philippines with raster-based tool built within GIS environment. Agric Informat Res 18(1):24-31

Aksoy H, Kavvas ML (2005) A review of hillslope and watershed scale erosion and sediment transport models. CATENA 64(2-3):247-271

Ambers RK (2001) Using the sediment record in a western Oregon floodcontrol reservoir to assess the influence of storm history and logging on sediment yield. J Hydrol 244(3-4):181-200

Amsalu T, Mengaw A (2014) GIS based soil loss estimation using rusle model: the case of jabi tehinan woreda, ANRS, Ethiopia. Natural Resour 05:616-626

Aneseyee AB, Elias E, Soromessa T, Feyisa GL (2020a) Land use/land cover change effect on soil erosion and sediment delivery in the Winike watershed, Omo Gibe Basin Ethiopia. Sci Total Environ 728:138776

Aneseyee AB, Soromessa T, Elias E (2020b) The effect of land use/land cover changes on ecosystem services valuation of Winike watershed, Omo Gibe basin, Ethiopia. Hum Ecol Risk Assess Int J 26(10):2608-2627

Angassa A (2014) Effects of grazing intensity and bush encroachment on herbaceous species and rangeland condition in southern Ethiopia. Land Degrad Dev 25(5):438-451

Asmamaw LB, Mohammed AA (2019) Identification of soil erosion hotspot areas for sustainable land management in the Gerado catchment, North-eastern Ethiopia. Remote Sens Appl Soc Environ 13:306-317

Bantider A (2007) Landscape Transformation and Opportunities for Sustainable Land Management along the Eastern Escarpment of Wello (EEW), Ethiopia (PhD dissertation). University of Bern, Switzerland

Baral H, Keenan RJ, Sharma SK, Stork NE, Kasel S (2014) Spatial assessment and mapping of biodiversity and conservation priorities in a heavily modified and fragmented production landscape in north-central Victoria, Australia. Ecol Ind 36:552-562

Belete MD (2013) The Impact of Sedimentation and Climate Variability on the Hydrological Status of Lake Hawassa, South Ethiopia (PhD dissertation). University of Bonn, Germany

Benavidez R, Jackson B, Maxwell D, Norton K (2018) A review of the (Revised) Universal Soil Loss Equation ((R) USLE): with a view to increasing its global applicability and improving soil loss estimates. Hydrol Earth Syst Sci 22(11):6059-6086

Bewket W (2003) Towards integrated watershed management in highland Ethiopia: the Chemoga Watershed case study (Ph.D dissertation). Wagningen University, Wagningen

Bewket W, Sterk G (2002) Farmers' participation in soil and water conservation activities in the Chemoga watershed, Blue Nile basin Ethiopia. Land Degradat Develop 13(3):189-200

Bewket W, Teferi E (2009) Assessment of soil erosion hazard and prioritization for treatment at the watershed level: case study in the Chemoga watershed, Blue Nile basin Ethiopia. Land Degradat Develop 20(6):609-622

Bezabih M, Duncan AJ, Adie A, Mekonnen K, Khan NA, Thorne P (2016) The role of irrigated fodder production to supplement the diet of fattening sheep by smallholders in southern Ethiopia. Tropic Subtropic Agroecosyst 19(3):263-275

Biggs EM, Bruce E, Boruff B, Duncan JM, Horsley J, Pauli N, McNeill K, Neef A, Van Ogtrop F, Curnow J, Haworth B (2015) Sustainable development 
and the water-energy-food nexus: a perspective on livelihoods. Environ Sci Policy 54:389-397

Blaikie P (2016) The political economy of soil erosion in developing countries. London, UK.

Boakye E, Anyemedu FOK, Donkor EA, Quaye-Ballard JA (2020) Spatial distribution of soil erosion and sediment yield in the Pra River Basin. SN Applied Sciences 2(3): 1-12

Borrelli P, Robinson DA, Fleischer LR, Lugato E, Ballabio C, Alewell C, Meusburger K, Modugno S, Schütt B, Ferro V, Bagarello V (2017) An assessment of the global impact of $21^{\text {st }}$ century land use change on soil erosion. Nat Commun 8(1):1-13

Borselli L, Cassi P, Torri D (2008) Prolegomena to sediment and flow connectivity in the landscape: a GIS and field numerical assessment. CATENA 75(3):268-277

Cavalli M, Trevisani S, Comiti F, Marchi L (2013) Geomorphometric assessment of spatial sediment connectivity in small Alpine catchments. Geomorphology 188:31-41

Chorowicz J (2005) The east African rift system. J Afr Earth Sci 43(1-3):379-410

Constable M, Belshaw D (1986) The Ethiopian highlands reclamation study: major findings and recommendations. In ONCCP (Office of the National Committee for Central Planning). Towards a food and nutrition strategy for Ethiopia: Proceedings of the national workshop on food strategies for Ethiopia (pp. 8-12).

De Graff J (1996) The price of soil erosion: an economic evaluation of soil erosion and watershed development (Ph.D. thesis). Wageningen Agricultural University, Wageningen, The Netherlands.

De Vente J, Poesen J (2005) Predicting soil erosion and sediment yield at the basin scale: scale issues and semi-quantitative models. Earth Sci Rev 71(1-2):95-125

De Vente J, Poesen J, Verstraeten G, Govers G, Vanmaercke M, Van Rompaey A, Arabkhedri M, Boix-Fayos C (2013) Predicting soil erosion and sediment yield at regional scales: where do we stand? Earth Sci Rev 127:16-29

Degife A, Worku H, Gizaw S, Legesse A (2019) Land use land cover dynamics, its drivers and environmental implications in Lake Hawassa Watershed of Ethiopia. Remote Sens Appl Soc Environ 14:178-190

deNoyelles F, Kastens JH (2016) Reservoir sedimentation challenges Kansas. Trans Kans Acad Sci 119(1):69-81

Desmet PJJ, Govers G (1996) A GIS procedure for automatically calculating the USLE LS factor on topographically complex landscape units. J Soil Water Conserv 51(5):427-433

Dessie G (2007) Forest Decline in South Central Ethiopia: Extent, history and process (Doctoral dissertation). Department of Physical Geography and Quaternary Geology, Stockholm University, SE-106 91 Stockholm, Sweden.

Desta H, Lemma B (2017) SWAT based hydrological assessment and characterization of Lake Ziway sub-watersheds, Ethiopia. J Hydrol Regional Stud 13:122-137

Erkossa T, Wudneh A, Desalegn B, Taye G (2015) Linking soil erosion to on-site financial cost: lessons from watersheds in the Blue Nile basin. Solid Earth 6(2):765-774

Esa E, Assen M, Legass A (2018) Implications of land use/cover dynamics on soil erosion potential of agricultural watershed, northwestern highlands of Ethiopia. Environ Syst Res 7(21):1-4

Esayas Y (2010) Evaluating the Impact of Land Use/Land Cover Change on Soil Erosion Runoff Using SWAT Model at Tikur Wuha Watershed (master's thesis). Addis Ababa University, Ethiopia

Eweg HPA, Lammeren RV (1996) The application of a geographical information system at the rehabilitation of degraded and degrading areas: a case study in the Highlands of Tigray, Ethiopia. The application of a geographical information system at the rehabilitation of degraded and degrading areas: a case study in the Highlands of Tigray, Ethiopia.

Eweg HPA, Van Lammeren R, Deurloo H, Woldu Z (1998) Analysing degradation and rehabilitation for sustainable land management in the highlands of Ethiopia. Land Degrad Dev 9(6):529-542

FAO (2006) Guidelines for soil description. FAO, Rome

Farhan Y, Nawaiseh S (2015) Spatial assessment of soil erosion risk using RUSLE and GIS techniques. Environ Earth Sci 74(6):4649-4669
FEl (Finnish Environment Institute) (2003) Guidelines on monitoring and assessment of transboundary and international lakes, Part B: Technical guidelines, Helsinki

Fenta AA, Tsunekawa A, Haregeweyn N, Poesen J, Tsubo M, Borrelli P, Panagos P, Vanmaercke M, Broeckx J, Yasuda H, Kawai T (2020) Land susceptibility to water and wind erosion risks in the East Africa region. Sci Total Environ 703:135016

Gashaw T, Tulu T, Argaw M (2018) Erosion risk assessment for prioritization of conservation measures in Geleda watershed, Blue Nile basin Ethiopia. Environ Syst Res 6(1):1-14

Gebreegziabher Y (2004) Assessment of the water balance of Lake Awassa catchment, Ethiopia (Master's thesis). ITC, Enschede

Gebre-Mariam Z, Desta Z (2002) The chemical composition of the effluent from Awassa textile factory and its effects on aquatic biota. SINET Ethiopian J Sci 25(2):263-274

Gelagay HS (2016) RUSLE and SDR model based sediment yield assessment in a GIS and remote sensing environment; a case study of Koga watershed, Upper Blue Nile Basin Ethiopia. Hydrol Curr Res 7:239

Gelagay HS, Minale AS (2016) Soil loss estimation using GIS and Remote sensing techniques: a case of Koga watershed, Northwestern Ethiopia. Int Soil Water Conservat Res 4(2):126-136

Geremew Z (2000) Engineering geological investigation and lake level changes in the Awassa basin (Master's thesis). Department of Geology and Geophysics. Addis Ababa University, Addis Ababa

Girma R, Gebre E (2020) Spatial modeling of erosion hotspots using GIS-RUSLE interface in Omo-Gibe river basin, Southern Ethiopia: implication for soil and water conservation planning. Environ Syst Res 9(1):1-14

Girmay G, Moges A, Muluneh A (2020) Estimation of soil loss rate using the USLE model for Agewmariayam Watershed, northern Ethiopia. Agric Food Secur 9(1):1-12

Hamel P, Chaplin-Kramer R, Sim S, Mueller C (2015) A new approach to modeling the sediment retention service (InVEST 3.0): case study of the cape fear catchment, North Carolina, USA. Sci Total Environ 524:166-177

Haregeweyn N, Poesen J, Deckers J, Nyssen J, Haile M, Govers G, Verstraeten G, Moeyersons J (2008) Sediment-bound nutrient export from micro-dam catchments in Northern Ethiopia. Land Degrad Dev 19(2):136-152

Haregeweyn N, Melesse B, Tsunekawa A, Tsubo M, Meshesha D, Balana BB (2012) Reservoir sedimentation and its mitigating strategies: a case study of Angereb reservoir (NW Ethiopia). J Soils Sediments 12(2):291-305

Haregeweyn N, Poesen J, Verstraeten G, Govers G, de Vente J, Nyssen J, Deckers J, Moeyersons J (2013) Assessing the performance of a spatially distributed soil erosion and sediment delivery model (WATEM/SEDEM) in Northern Ethiopia. Land Degrad Dev 24(2):188-204

Haregeweyn N, Tsunekawa A, Nyssen J, Poesen J, Tsubo M, Tsegaye Meshesha D, Schütt B, Adgo E, Tegegne F (2015) Soil erosion and conservation in Ethiopia: a review. Prog Phys Geogr 39(6):750-774

Haregeweyn N, Tsunekawa A, Poesen J, Tsubo M, Meshesha DT, Fenta AA, Nyssen J, Adgo E (2017) Comprehensive assessment of soil erosion risk for better land use planning in river basins: case study of the upper blue Nile River. Sci Total Environ 574:95-108

Hassen EE, Assen M (2018) Land use/cover dynamics and its drivers in Gelda catchment, Lake Tana watershed, Ethiopia. Environ Syst Res 6(1):1-13

Hernandez EC, Henderson A, Oliver DP (2012) Effects of changing land use in the Pagsanjan-Lumban catchment on suspended sediment loads to Laguna de Bay, Philippines. Agric Water Manag 106:8-16

Hurni, H., 1983. Soil formation rates in Ethiopia. Ethiopian highlands reclamation study. Soil Conservation Research Project, FAO, UTF/ETH/037/ETH Working Paper 2.

Hurni, H., 1985. Erosion-productivity-conservation systems in Ethiopia. Proceedings of the 4th International Conference on Soil Conservation. Maracay, Venezuela. pp. 654-674.

Hurni, H., 1986. Guidelines for development agents on soil conservation in Ethiopia. Soil conservation research project, Community Forests and Soil Conservation Development Department, Ministry of Agriculture, Addis Ababa, Ethiopia.

Hurni H (1993) Land degradation, famine, and land resource scenarios in Ethiopia. In: Pimentel D (ed) world soil erosion and conservation. Cambridge University Press, Cambridge, pp 27-62 
Hurni $\mathrm{H}$ (2002) Current international actions for furthering the sustainable use of soils. In: 17. World congress of soil science, Bangkok (Thailand), 14-21 Aug 2002.

Ionita I, Fullen MA, Zgłobicki W, Poesen J (2015) Gully erosion as a natural and human-induced hazard. Nat Hazards 79:1-5

Issaka S, Ashraf MA (2017) Impact of soil erosion and degradation on water quality: a review. Geo Ecol Landscapes 1(1):1-11

Jahun BG, Ibrahim R, Dlamini NS, Musa SM (2015) Review of soil erosion assessment using RUSLE model and GIS. J Biol Agric Healthc 5(9):36-47

Jansson MB (1988) A global survey of sediment yield. Geogr Ann Ser B 70(1-2):81-98

Kaltenrieder, J., 2007. Adaption and Validation of the Universal Soil Loss Equation (USLE) for the Ethiopian-Eritrean Highlands (MSc Thesis). Centre for Development and Environment, Geographisches Institut, University of Bern, Bern.

Karabulut A, Egoh BN, Lanzanova D, Grizzetti B, Bidoglio G, Pagliero L, Bouraoui F, Aloe A, Reynaud A, Maes J, Vandecasteele I (2016) Mapping water provisioning services to support the ecosystemwater-food-energy nexus in the Danube river basin. Ecosyst Serv 17:278-292

Karaburun A (2010) Estimation of C factor for soil erosion modeling using NDVI in Buyukcekmece watershed. Ozean J Appl Sci 3(1):77-85

Kinnell PIA (2010) Event soil loss, runoff and the Universal Soil Loss Equation family of models: a review. J Hydrol 385(1-4):384-397

Kouli M, Soupios P, Vallianatos F (2009) Soil erosion prediction using the revised universal soil loss equation (RUSLE) in a GIS framework, Chania, Northwestern Crete, Greece. Environ Geol 57(3):483-497

Lafforgue M (2016) Impact of forests on water quality. Forest and the water cycle: quantity, quality, management. Cambridge Scholar Publishing, Newcastle upon Tyne, pp 204-265

Li J, Heap AD (2008) A review of spatial interpolation methods for environmental scientists. Geoscience Australia 2008/2003.

LIA (Lake Illawarra Authority) (2011) Lake Illawarra Authorit's Annual Report 2010/11, Sydney

Lin D, Gao Y, Wu Y, Shi P, Yang H, Wang JA (2017) A conversion method to determine the regional vegetation cover factor from standard plots based on large sample theory and TM images: a case study in the eastern farming-pasture ecotone of northern China. Remote Sensing 9(10):1035

López-Vicente M, Poesen J, Navas A, Gaspar L (2013) Predicting runoff and sediment connectivity and soil erosion by water for different land use scenarios in the Spanish Pre-Pyrenees. CATENA 102:62-73

Macgregor D (2015) History of the development of the East African Rift system: a series of interpreted maps through time. J Afr Earth Sc 101:232-252

Merritt WS, Croke BFW, Jakeman AJ, Letcher RA, Perez P (2004) A biophysical toolbox for assessment and management of land and water resources in rural catchments in Northern Thailand. Ecol Model 171(3):279-300

Meshesha DT, Tsunekawa A, Tsubo M, Haregeweyn N (2012) Dynamics and hotspots of soil erosion and management scenarios of the Central Rift Valley of Ethiopia. Int J Sedim Res 27(1):84-99

Mitasova H, Mitas L (1999) Modeling soil detachment with RUSLE 3D using GIS. University of Illinois at Urbana-Champaign, Champaign

Moges DM, Bhat HG (2017) Integration of geospatial technologies with RUSLE for analysis of land use/cover change impact on soil erosion: case study in Rib watershed, north-western highland Ethiopia. Environ Earth Sci 76(22):765

Moore ID, Burch GJ (1986) Physical basis of the length-slope factor in the Universal soil loss equation. Soil Sci Soc Am J 50(5):1294-1298

Moore ID, Wilson JP (1992) Length-slope factors for the revised Universal soil loss equation: simplified method of estimation. I Soil Water Conserv 47(5):423-428

Morgan RPC (1995) Measurement of soil erosion. Soil Erosion and Conservation, 2nd Edition. Longman, Essex, UK, pp. 84-95.

Morgan RPC (2009) Soil erosion and conservation. Wiley

Moussa, A.M.A., 2018. Assessment of Sediment Deposition in Aswan High Dam Reservoir During 50 Years (1964-2014). In: Grand Ethiopian Renaissance Dam Versus Aswan High Dam (pp. 233-253). Cham: Springer

Nagle GN, Fahey TJ, Lassoie JP (1999) Management of sedimentation in tropical watersheds. Environ Manage 23(4):441-452
Naipal V, Reick C, Pongratz J, Oost KV (2015) Improving the global applicability of the RUSLE model-adjustment of the topographical and rainfall erosivity factors. Geoscientific Model Develop 8(9):2893-2913

Nakil M, Khire M (2016) Effect of slope steepness parameter computations on soil loss estimation: review of methods using GIS. Geocarto Int 31(10):1078-1093

Navas A, Valero-Garcés B, Gaspar L, Machín J (2009) Reconstructing the history of sediment accumulation in the Yesa reservoir: an approach for management of mountain reservoirs. Lake Reservoir Manage 25(1):15-27

Nontananandh S, Changnoi B (2012) Internet GIS, based on USLE modeling, for assessment of soil erosion in Songkhram Watershed, Northeastern of Thailand. Agricu Nat Resour 46(2):272-282

Oliveira AH, da Silva MA, Silva MLN, Curi N, Neto GK, de Freitas DAF (2013) Development of topographic factor modeling for application in soil erosion models, In: Intechopen (Ed.), Soil Processes and Current Trends in Quality Assessment. Rijeka: InTech, (4), pp.111-138.

Panagos P, Borrelli P, Meusburger K, van der Zanden EH, Poesen J, Alewell $C$ (2015) Modelling the effect of support practices (P-factor) on the reduction of soil erosion by water at European scale. Environ Sci Policy 51:23-34

Piccarreta M, Capolongo D, Boenzi F, Bentivenga M (2006) Implications of decadal changes in precipitation and land use policy to soil erosion in Basilicata, Italy. CATENA 65(2):138-151

Pimentel D (2006) Soil erosion: a food and environmental threat. Environ Dev Sustain 8(1):119-137

Prasannakumar V, Vijith H, Abinod S, Geetha NJGF (2012) Estimation of soil erosion risk within a small mountainous sub-watershed in Kerala, India, using Revised Universal Soil Loss Equation (RUSLE) and geo-information technology. Geosci Front 3(2):209-215

Redhead JW, Stratford C, Sharps K, Jones L, Ziv G, Clarke D, Oliver TH, Bullock JM (2016) Empirical validation of the InVEST water yield ecosystem service model at a national scale. Sci Total Environ 569:1418-1426

Renard KG, Foster GR, Weesies GA, Porter JP (1991) RUSLE: revised universal soil loss equation. J Soil Water Conserv 46(1):30-33

Renard KG, Foster GR, Weesies GA, McCool DK, Yoder DC (1997) Predicting soil erosion by water: a guide to conservation planning with the Revised Universal Soil Loss Equation (RUSLE). United States Department of Agriculture, Washington, DC, p 703

Rodrigo Comino J, Brings C, Lassu T, Iserloh T, Senciales JM, Martínez Murillo JF, Ruiz Sinoga JD, Seeger M, Ries JB (2015) Rainfall and human activity impacts on soil losses and rill erosion in vineyards (Ruwer Valley, Germany). Solid Earth 6(3):823-837

Römkens MJM, Young RA, Poesen JWA, McCool DK, El-Swaify SA, Bradford JM (1997) Soil erodibility factor (K). Predicting Soil Erosion by Water: A Guide to Conservation, edited by: Renard, KG, Foster, GR, Weesies, GA, McCool, DK, and Yoder, DC, coordinators, Planning with the Revised Universal Soil Loss Equation (RUSLE), US Department of Agriculture, Agriculture Handbook, (703), pp. 65-99.

Sadeghi SHR, Mizuyama T, Miyata S, Gomi T, Kosugi K, Fukushima T, Mizugaki S, Onda Y (2008) Development, evaluation and interpretation of sediment rating curves for a Japanese small mountainous reforested watershed. Geoderma 144(1-2):198-211

Sadeghi SHR, Gholami L, Khaledi Darvishan A, Saeidi P (2014) A review of the application of the MUSLE model worldwide. Hydrol Sci J 59(2):365-375

Sahle M, Saito O, Fürst C, Yeshitela K (2019) Quantifying and mapping of water-related ecosystem services for enhancing the security of the food-water-energy nexus in tropical data-sparse catchment. Sci Total Environ 646:573-586

Schmalz B, Kruse M, Kiesel J, Müller F, Fohrer N (2016) Water-related ecosystem services in Western Siberian lowland basins - analysing and mapping spatial and seasonal effects on regulating services based on ecohydrological modelling results. Ecol Ind 71:55-65

Schmitt LK (2009) Developing and applying a soil erosion model in a datapoor context to an island in the rural Philippines. Environ Dev Sustain 11(1):19-42

SCRP (Soil Conservation Research Project) (1996) Soil erosion hazard assessment for land evaluation. Research report, SCRP, Addis Ababa

Sharma PN (1999). An overview of recent concepts and participatory integrated watershed management (PIWM) processes. In: B.R Bhatta, SR Chalise, AK Myint and P Sharma (eds.) Recent concepts, knowledge, 
practices and new skills in participatory integrated watershed management: trainers' resource book. Kathamandu.

Sharma A, Tiwari KN, Bhadoria PBS (2011) Effect of land use land cover change on soil erosion potential in an agricultural watershed. Environ Monit Assess 173(1-4):789-801

Sharp R, Tallis HT, Ricketts T, Guerry AD, Wood SA, Chaplin-Kramer R, Nelson E, Ennaanay D, Wolny S, Olwero N, Vigerstol K, Pennington D, Mendoza G, Aukema J, Foster J, Forrest J, Cameron D, Arkema K, Lonsdorf E, Kennedy C, Verutes G, Kim CK, Guannel G, Papenfus M, Toft J, Marsik M, Bernhardt J, Griffin R, Glowinski K, Chaumont N, Perelman A, Lacayo M, Mandle L, Hamel P, Vogl AL, Rogers L, Bierbower W, Denu D, Douglass J (2018). InVEST 3.50.post225+h6aabb7740548 User's Guide. The Natural Capital Project, Stanford University, University of Minnesota, The Nature Conservancy, and World Wildlife Fund.

Shiferaw A (2011) Estimating soil loss rates for soil conservation planning in the Borena Woreda of South Wollo Highlands, Ethiopia. J Sustain Develop Afr 13(3):87-106

Simms AD, Woodroffe CD Jones BG (2003) Application of RUSLE for erosion management in a coastal catchment, southern NSW. In: Proceedings of the international congress on modeling and simulation: integrative.

Swarnkar S, Malini A, Tripathi S, Sinha R (2018) Assessment of uncertainties in soil erosion and sediment yield estimates at ungauged basins: an application to the Garra River basin India. Hydrol Earth Syst Sci 22(4):2471-2485

Syvitski JP, Milliman JD (2007) Geology, geography, and humans battle for dominance over the delivery of fluvial sediment to the coastal ocean. J Geol 115(1):1-19

Tamene L, Abegaz A, Aynekulu E, Woldearegay K, Vlek PL (2011) Estimating sediment yield risk of reservoirs in northern Ethiopia using expert knowledge and semi-quantitative approaches. Lakes Reserv Res Manag 16(4):293-305

Tamene L, Le QB, Vlek PL (2014) A landscape planning and management tool for land and water resources management: an example application in northern Ethiopia. Water Resour Manage 28(2):407-424
Tarboton DG (1997) A new method for the determination of flow directions and upslope areas in grid digital elevation models. Water Resour Res 33(2):309-319

Tully K, Sullivan C, Weil R, Sanchez P (2015) The state of soil degradation in Sub-Saharan Africa: baselines, trajectories, and solutions. Sustainability 7(6):6523-6552

Vigiak O, Borselli L, Newham LTH, Mclnnes J, Roberts AM (2012) Comparison of conceptual landscape metrics to define hillslope-scale sediment delivery ratio. Geomorphology 138(1):74-88

Wilson JP, Gallant JC (eds) (2000) Terrain analysis: principles and applications. Wiley, Hoboken

Wischmeier WH, Smith DD (1978) Predicting rainfall erosion losses: a guide to conservation planning US Department of Agriculture, Science and Education Administration. Agriculture Handbook, Washington DC, p 537

Wolka K, Tadesse H, Garedew E, Yimer F (2015) Soil erosion risk assessment in the Chaleleka wetland watershed, Central Rift Valley of Ethiopia. Environ Syst Res 4(1):1-12

Yesuph AY, Dagnew AB (2019) Soil erosion mapping and severity analysis based on RUSLE model and local perception in the Beshillo Catchment of the Blue Nile Basin Ethiopia. Environ Syst Res 8(17):1-21

Zeleke, G., 2000. Landscape dynamics and soil erosion process modelling in the north-western Ethiopian highlands. African Studies Series A16. Geographica Bernensia, Berne.

Zerihun M, Mohammedyasin MS, Sewnet D, Adem AA, Lakew M (2018) Assessment of soil erosion using RUSLE, GIS and remote sensing in NW Ethiopia. Geoderma Reg 12:83-90

\section{Publisher's Note}

Springer Nature remains neutral with regard to jurisdictional claims in published maps and institutional affiliations.

\section{Submit your manuscript to a SpringerOpen ${ }^{\circ}$ journal and benefit from:}

- Convenient online submission

- Rigorous peer review

- Open access: articles freely available online

- High visibility within the field

- Retaining the copyright to your article

Submit your next manuscript at $\boldsymbol{\nabla}$ springeropen.com 